\title{
May 2018
}

\section{Energy Futures Synthesis for West-Wide Section 368 Energy Corridors}

Authors: Barbara O'Neill, Doug Gagne, Jeff Cook, and Tessa Greco National Renewable Energy Laboratory

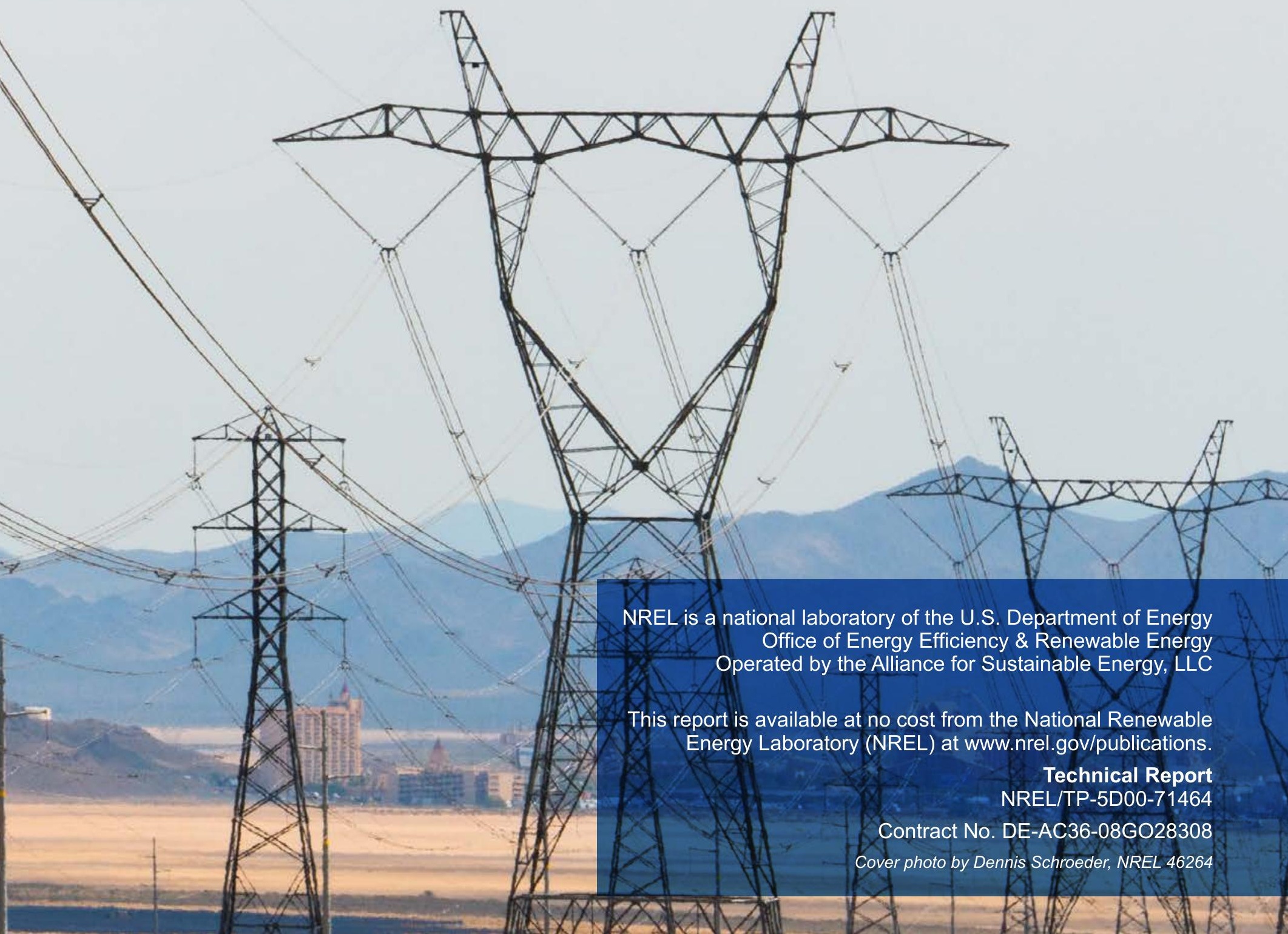




\title{
Energy Futures Synthesis for West-Wide Section 368 Energy Corridors
}

\author{
Barbara O'Neill, Doug Gagne, Jeff Cook, \\ and Tessa Greco \\ National Renewable Energy Laboratory
}

Prepared under Task No. WFED.10422.01.01.01

NREL is a national laboratory of the U.S. Department of Energy

Office of Energy Efficiency \& Renewable Energy

Operated by the Alliance for Sustainable Energy, LLC

This report is available at no cost from the National Renewable Energy Laboratory (NREL) at www.nrel.gov/publications.

National Renewable Energy Laboratory 15013 Denver West Parkway

Golden, CO 80401

303-275-3000 • www.nrel.gov

\section{Technical Report}

NREL/TP-5D00-71464

May 2018

Contract No. DE-AC36-08G028308 


\section{NOTICE}

This report was prepared as an account of work sponsored by an agency of the United States government. Neither the United States government nor any agency thereof, nor any of their employees, makes any warranty, express or implied, or assumes any legal liability or responsibility for the accuracy, completeness, or usefulness of any information, apparatus, product, or process disclosed, or represents that its use would not infringe privately owned rights. Reference herein to any specific commercial product, process, or service by trade name, trademark, manufacturer, or otherwise does not necessarily constitute or imply its endorsement, recommendation, or favoring by the United States government or any agency thereof. The views and opinions of authors expressed herein do not necessarily state or reflect those of the United States government or any agency thereof.

This report is available at no cost from the National Renewable Energy Laboratory (NREL) at www.nrel.gov/publications.

Available electronically at SciTech Connect http:/www.osti.gov/scitech

Available for a processing fee to U.S. Department of Energy and its contractors, in paper, from:

U.S. Department of Energy

Office of Scientific and Technical Information

P.O. Box 62

Oak Ridge, TN 37831-0062

OSTI http://www.osti.gov

Phone: 865.576.8401

Fax: 865.576.5728

Email: reports@osti.gov

Available for sale to the public, in paper, from:

U.S. Department of Commerce

National Technical Information Service

5301 Shawnee Road

Alexandria, VA 22312

NTIS http://www.ntis.gov

Phone: 800.553 .6847 or 703.605 .6000

Fax: 703.605.6900

Email: orders@ntis.gov 


\section{Acknowledgments}

The authors thank Georgeann Smale, Jim Gazewood, and Jeremy Bluma of the U.S. Department of Interior's Bureau of Land Management for their continuous support of and contributions to this project. In addition, we acknowledge Argonne National Laboratory staff Jim Kuiper and Konnie Wescott for helping with the maps in the report. The authors thank Dave Hurlbut of the National Renewable Energy Laboratory (NREL) for the extensive review he provided. We also thank Scott Haase of NREL for initiating this work as well as the continuous support and review. We want to acknowledge Jennie Jorgensen and Dave Corbus at NREL for their comments as well as Nicholas Gilroy from NREL's geospatial team for the great work on many of the maps. 


\section{List of Acronyms}

BLM

DOE

EIA

EIM

EPAct

IRP

NREL

PNM

SEZ

TEP

TEPPC

WECC

WREZ
U.S. Bureau of Land Management

U.S. Department of Energy

U.S. Energy Information Administration

Energy Imbalance Market

Energy Policy Act of 2005

Integrated resource plan

National Renewable Energy Laboratory

Public Service Company of New Mexico

Solar Energy Zone

Tucson Electric Power

Transmission Expansion Planning Policy

Committee (of the Western Electricity Coordinating

Council)

Western Electricity Coordinating Council

Western Renewable Energy Zone 


\section{Executive Summary}

To comply with Section 368(a) of the Energy Policy Act of 2005 (EPAct), the U.S. Bureau of Land Management (BLM) and the U.S. Forest Service designated 6,000 miles of energy corridors on public and national forest lands in the western United States in 2009. The corridors, commonly referred to as "West-wide" or "Section 368" energy corridors, are intended as preferred locations for future siting of electric transmission and distribution lines and for oil, gas, and hydrogen pipelines.

In response to a lawsuit filed by several organizations ${ }^{1}$ over the corridor designations, the BLM, Forest Service, and the U.S. Department of Energy entered into a Settlement Agreement, ${ }^{2}$ directing the formation of the Section 368 Interagency Workgroup to periodically review the energy corridors on a regional basis. In conducting the reviews, the Workgroup identifies new, relevant, existing, publicly available information to make recommendations for revisions, deletions, and additions to the Section 368 energy corridors.

This report synthesizes information in available contemporary transmission, pipeline, and energy future studies to inform the regional reviews by providing a snapshot of what the western energy and transmission system will look like generally 10-15 years in the future. After an overview of the western grid implications, the analysis narrows to Region 2 and Region 3 of the BLM Section 368 energy corridors and focuses on the implications of potential developments in the oil, natural gas, and electricity markets in Colorado, New Mexico, Utah, and portions of Arizona and Nevada that could inform the current regional review. This analysis will help inform the Workgroup on potential development within existing corridors and the need for new corridors that have not yet been designated.

In the reference case scenarios (those using most-likely occurring assumptions) of the examined West-wide electricity studies, regional transmission capacity was mostly sufficient to meet demand in the West-wide energy corridor review Region 2 and Region 3 through the study periods (typically 2026-2030). As such, future demand for new electricity transmission lines within the Section 368 energy corridors during this time would be anticipated to be relatively low. Similarly, there is low to moderate expected demand for oil and natural gas pipeline development in the West through the study period; however, the supply, distribution, and use of energy is undergoing rapid and profound changes, regionally and nationally, and has potential to be significantly different than predicted.

Within the examined studies, there are several alternative potential scenarios where electricity transmission capacity will be insufficient or where specific transmission lines close to Section 368 energy corridors will be near their maximum capacity and could not support high penetrations of renewable electricity. For those potential scenarios, there might

\footnotetext{
${ }^{1}$ Plaintiffs for the lawsuit include The Wilderness Society, BARK, Center for Biological Diversity, Defenders of Wildlife, Great Old Broads for Wilderness, Klamath-Siskiyou Wildlands Center, National Parks Conservation Association, National Trust for Historic Preservation, Natural Resources Defense Council, Oregon Natural Desert Association, Sierra Club, Southern Utah Wilderness Alliance, Western Resource Advocates, Western Watersheds Project, and San Miguel County, Colorado.

${ }^{2}$ The settlement agreement can be found at

http://corridoreis.anl.gov/documents/docs/Settlement_Agreement_Package.pdf.
} 
be future demand for Section 368 energy corridors and for modifications or additions to the West-wide energy corridor network.

This report represents an overview of studies published between 2014 and 2017 (see References) and is based on conditions during this time. This report is drawn from publicly available sources and does not attempt to construct scenarios or conduct analysis of transmission topologies. The cited studies project patterns of future electricity needs, which are subject to economic and policy uncertainties that could significantly affect their conclusions. Therefore, as envisioned by Section 368 of the EPAct, it would be prudent to undertake an adaptive management approach regarding the West-wide energy corridor network to appropriately plan and respond to changing energy demands.

Figure ES-1 shows the six regions for review under the Section 368 review process as well as the designated energy corridors. This report specifically examines Region 2 and Region 3, highlighted in pink and green.

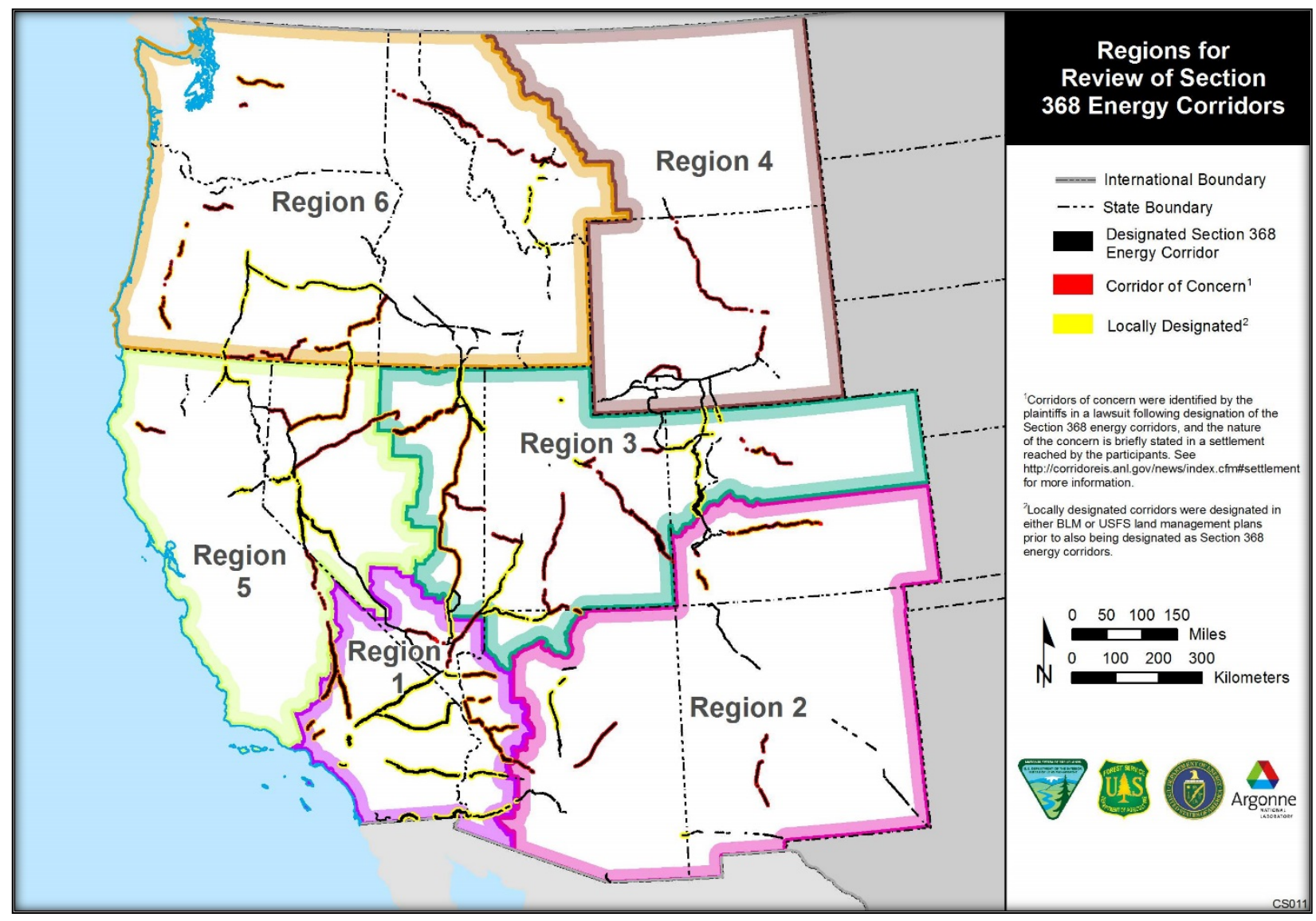

Source: Argonne National Laboratory

Figure ES-1. Section 368 energy corridor region overview 


\section{Table of Contents}

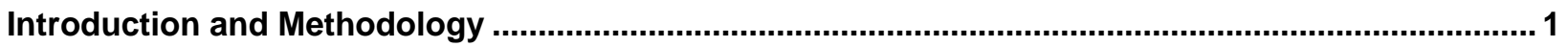

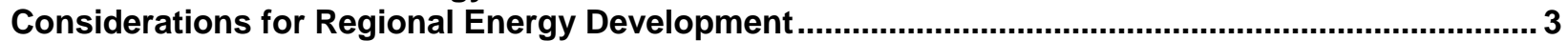

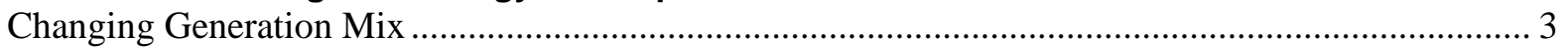

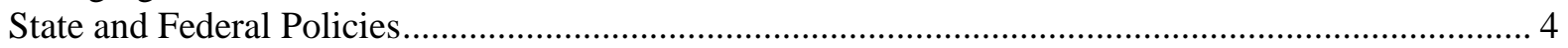

Decreasing Costs of Natural Gas and Renewable Energy Generation ................................................. 6

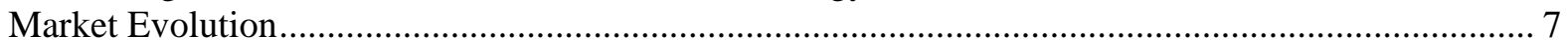

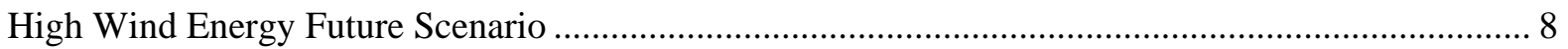

Western Electricity Coordinating Council Common Case Scenario for Transmission Expansion........ 9

Electric Transmission Planning: Region 2 and Region 3 ........................................................ 11

WECC Transmission Path Implications for Region 2 and Region 3......................................... 11

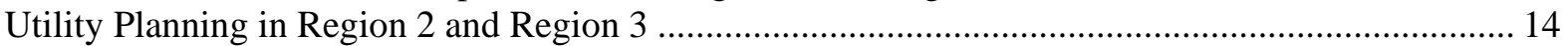

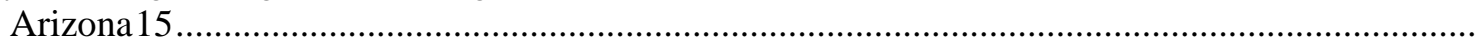

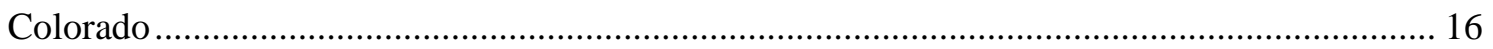

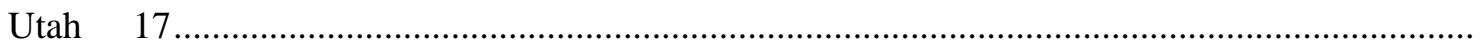

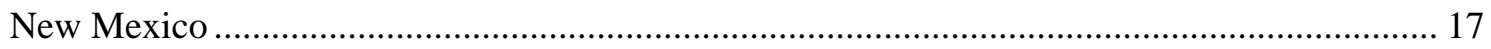

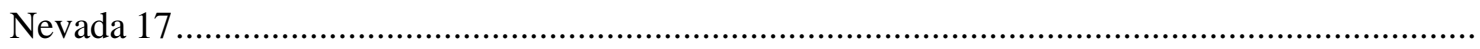

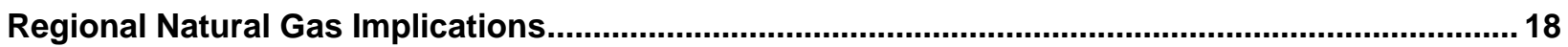

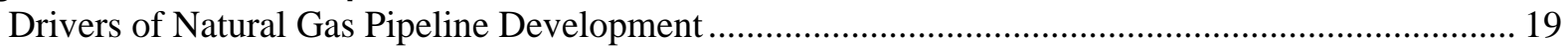

Natural Gas Pipeline Development Considerations for Region 2 and Region 3.............................. 19

Summary of Implications for Section 368 Corridors in Region 2 and Region 3...............................21

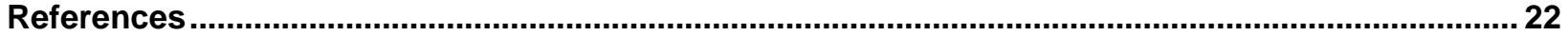




\section{List of Figures}

Figure ES-1. Section 368 energy corridor region overview .............................................................. vi

Figure 1. U.S. net generation mix (2016-2026) ............................................................................ 4

Figure 2. Highlighted proposed transmission lines and Section 368 corridors with SEZ and WREZ ........ 7

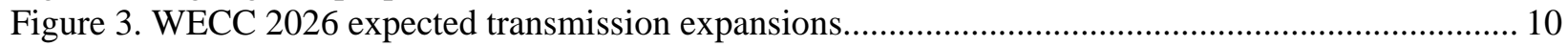

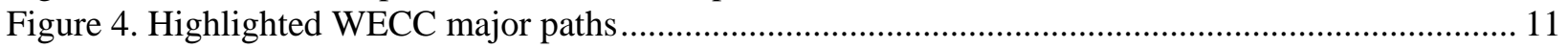

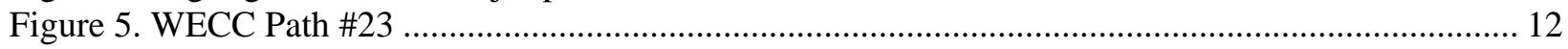

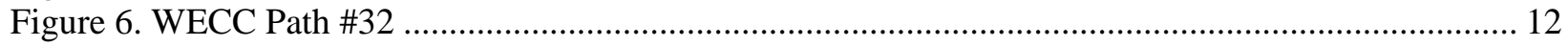

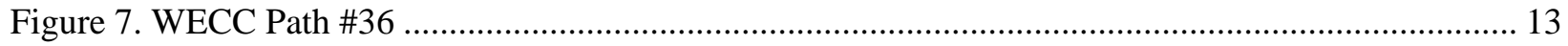

Figure 8. WECC Path \#47 .................................................................................................................. 13

Figure 9. Service territories of investor-owned utilities with published integrated resource plans ............ 15

Figure 10. Highlighted proposed pipelines and Section 368 corridors ................................................... 18

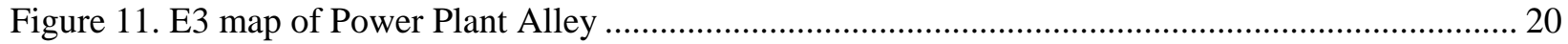

\section{List of Tables}

Table 1. Renewable Portfolio Standard Requirements and Goals in the West .......................................... 5

Table 2. Congested WECC Paths under Alternative Scenarios.............................................................. 14 


\section{Introduction and Methodology}

To comply with Section 368 of the Energy Policy Act of 2005 (EPAct), the U.S. Bureau of Land Management (BLM) designated approximately 5,000 miles of West-wide energy corridors on public lands in the 11 contiguous western states through a 2009 Record of Decision that amended 92 land use plans. The U.S. Forest Service also issued a Record of Decision amending 38 Forest Service land management plans and designating approximately 990 miles of corridors in 10 western states. The corridors, referred to as "West-wide" or "Section 368" energy corridors, are intended for expedited permitting of electric transmission and distribution lines and for oil, gas, and hydrogen pipelines.

Under the terms of the Settlement Agreement in 2012, the BLM, Forest Service, and the U.S. Department of Energy (DOE) formed the Section 368 Interagency Workgroup to consider the following general corridor siting principles while reviewing the existing energy corridors for potential revisions, deletions, or additions:

- Corridors provide maximum utility and minimum impact to the environment.

- Corridors promote efficient use of landscape for necessary development.

- Appropriate and acceptable uses are defined for specific corridors.

- Corridors provide connectivity to renewable energy generation to the maximum extent possible while considering other generation.

This report represents a synthesis of publicly available studies on West-wide electricity and pipeline transmission and energy futures to assist in the consideration of the siting principles during the reviews. The National Renewable Energy Laboratory (NREL) considered numerous studies and sources of information, including those recommended in Section II.A.1.b. of the Settlement Agreement. This report does not include new analyses but instead involved the compilation and survey of 83 studies related to the West or subregions therein. These studies included those from the Western Electricity Coordinating Council (WECC), the Western Governors Association, BLM, states, utilities, consulting firms, and research laboratories.

More than 20 specific studies were analyzed in detail for key implications concerning the Section 368 corridors in the West and more specifically in Region 2 and Region 3. The studies focused on issues such as transmission planning, integrated resource planning, oil and natural gas pipelines, natural gas futures, and renewable energy demand during a study horizon of 10-15 years. Of these, electricity studies were chosen with a preference for production cost modelbased analysis, which helped to ground the analysis in quantitative, rather than qualitative, projections. Production cost models are used to forecast the expected amount of electricity required from the grid, the power generation units that will meet this need, and transmission lines that will deliver the power. Gas studies used hydraulic modeling to evaluate the balance of needs and transport, or pipeline flow.

Impacts on Section 368 corridors were identified by comparing the findings of multiple studies and examining where Section 368 corridors overlapped with areas of forecasted growth in transmission or pipeline demand. Where these needs overlapped with Section 368 corridors, NREL also examined the high-level economic potential for prospective corridor development 
from a supply and demand perspective (considering where the development of new generation and the likely end market for the power demand might be located).

Generally, new transmission line development is largely driven by the need to transmit electricity to a load-serving electric utility service territory, but it is constrained by the need for cost recovery, financing of infrastructure, and the ability to permit and site proposed transmission lines in a timely manner. In the western region, retiring generation could free up capacity on associated transmission lines, which could reduce the need for new transmission development; however, additional transmission development might be needed to deliver electricity from new renewable generation built farther from population centers (project sites with good wind and solar resources near transmission and load areas will have been developed first).

Among other references, additional information on electricity markets can be found in the 2017 DOE Staff Report to the Secretary on Electricity Markets and Reliability (DOE 2017), which highlights the regional and national changes in electricity markets that can impact new transmission development. In addition, a 2012 Western Governors Association report, Renewable Resources and Transmission in the West: Interviews on the Western Renewable Energy Zones Initiative (Schwartz 2012) provides valuable insights, despite its vintage, from transmission decision-makers on factors specifically influencing transmission that might be built to bring remote renewable generation to willing buyers.

This report is separated into two sections. The first section explores likely development scenarios and major drivers of electricity transmission demand, both West-wide and in Region 2 and Region 3. The second section includes a similar analysis for natural gas and oil pipelines. This analysis is intended to inform consideration of the general siting principles in reviewing the Section 368 energy corridors for potential revisions, deletions, or additions. 


\section{Considerations for Regional Energy Development}

Across the West, utilities are making investment decisions driven by generator retirements and load growth, with state and federal policies and changing technology costs directing new procurements toward renewable and natural gas generation. These investment decisions are contributing to a rapidly changing electric generation mix. For example, since 2001 coal generation's share of net generation across the West has fallen from 35\% in 2001 to $22 \%$ in 2016. During the same time span, natural gas has increased from $11 \%$ to $30 \%$ of net generation, and renewables have increased their share to 13\% (WECC 2018). Although natural gas generation facilities are generally located relatively close to the areas they serve, utility-scale renewable generation is quite often located in remote areas that require new transmission development.

\section{Changing Generation Mix}

The changing generation mix in the West will be a major driver for future demand for transmission and pipeline expansion. ${ }^{3}$ Based on the U.S. Energy Information Administration (EIA) Annual Energy Outlook 2018 (EIA 2018b), renewable and natural gas generation is expected to continue to grow as part of the generation mix. Figure 1 shows the EIA reference case projections for the U.S. net generation mix through 2026.

${ }^{3}$ For more information that supports this conclusion, please see DOE (2017). 


\section{Electricity Capacity: Electric Power Sector: Power Only}

Case: Reference case

GW

300

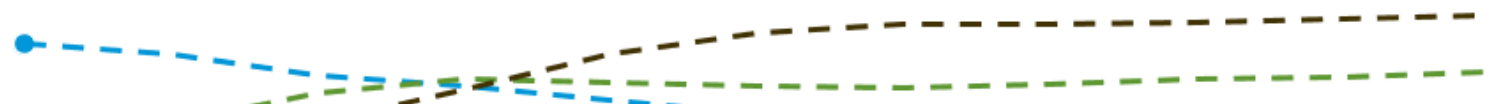

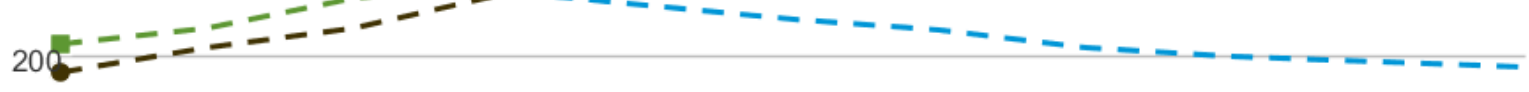

$10 \%$ ニே- - - - - - - - - - - - - - - - - - - - - - - - - - - -

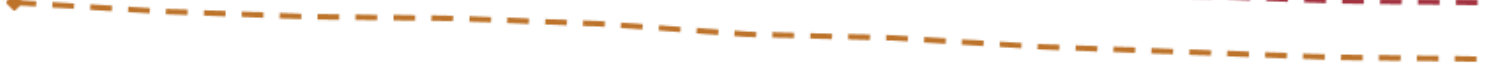

$$
20162018 \quad 2020 \quad 2022
$$

- Coal - Oil and Natural Gas Steam — Combined Cycle — Combustion Turbine/Diesel

- Nuclear - Renewable Sources

eia

Source: U.S. Energy Information Administration

Source: EIA (2018a)

Figure 1. U.S. net generation mix (2016-2026)

\section{State and Federal Policies}

Although generation cost is the main driver, some of the projected decline in coal, nuclear, and older oil and natural gas generation (especially natural gas-fired steam turbines as opposed to combustion turbines), and historical increase in renewable generation, can be explained by state and federal policies. For example, California enacted Senate Bill 1368 in 2006, which requires all utilities in the state to stop new investment in coal-powered plants unless the plant can demonstrate carbon emissions equivalent to the carbon emissions rate of a natural gas combinedcycle plant (State of California 2006). State policy has also driven announced retirements of California's two large nuclear power plants, as well as older natural gas plants, with a need for replacement power that the state has said must come partially from renewable energy (Nikolewski 2018).

In addition, 9 of the 11 states across the Western Interconnection have adopted renewable portfolio standards or renewable procurement goals (see Table 1). These policies require obligated utilities to procure new renewable energy generation to meet their load, which might 
require additional interconnection infrastructure if the renewables are remote or if a significant amount of wind and solar generation calls for new transmission to maintain grid reliability. ${ }^{4}$

Table 1. Renewable Portfolio Standard Requirements and Goals in the West

\begin{tabular}{lcc}
\hline \multicolumn{1}{|c}{ State } & $\begin{array}{c}\text { Renewable Portfolio } \\
\text { Standards Requirement }\end{array}$ & $\begin{array}{c}\text { In-State } \\
\text { Stipulations }\end{array}$ \\
\hline Arizona & $15 \%$ by 2025 & $\checkmark$ \\
\hline California & $50 \%$ by 2030 & $\checkmark$ \\
\hline Colorado & $30 \%$ by 2020 & $\checkmark$ \\
\hline Montana & $15 \%$ by 2015 & $\checkmark$ \\
\hline New Mexico & $20 \%$ by 2020 & $\checkmark$ \\
\hline Nevada & $25 \%$ by 2025 & \\
\hline Utah & $20 \%$ by 2025 & \\
\hline Washington & $15 \%$ by 2020 & $\checkmark$ \\
\hline Source: Lawrence Berkeley National Laboratory (2017)
\end{tabular}

Six of these states also have requirements or stipulations that favor in-state generation. California's policy is the most significant, given that it represents the largest demand for renewable power across the West and requires $75 \%$ of procurement to come from facilities with a first point of interconnection within or directly into a California balancing authority area (State of California 2015). Note that in California major investor-owned utilities have several power purchase agreements with out-of-state projects - located in Arizona, Nevada, and Utah-that meet this requirement because they have a first point of interconnection into a California balancing authority area (California Public Utilities Commission 2018).

Two states in Region 2 and Region 3-New Mexico and Arizona-have historically procured a majority of in-state capacity, and the integrated resource plan (IRP) for the Public Service Company of New Mexico (PNM), for example, assumes that new resources would be sited within the PNM territory (PNM 2014).

In the future, policies concerning the out-of-state purchase of renewables could influence utility energy procurement decisions and the need for additional interstate transmission capacity (DOE 2015b).

As noted in the 2017 DOE Staff Report on Electricity Markets and Reliability, federal policies offering tax subsidies for renewable generation and federal environmental and safety regulations that affect fossil-fueled and nuclear electric generation have also played a role in the fastchanging electric generation mix in the West. In addition, increasing corporate and private sector demand for renewables, including large procurements by companies such as Google, have also driven renewable energy development.

\footnotetext{
${ }^{4}$ Transmission planning is done with electricity reliability requirements in mind, not only to connect generation with distant load. Thus, transmission path redundancy is necessary to not overload neighboring paths, and therefore grid expansion is sometimes undertaken for reliability purposes.
} 


\section{Decreasing Costs of Natural Gas and Renewable Energy Generation}

In addition to state and federal policies and subsidies, decreasing technology costs have influenced utility procurement decisions. In recent years, the costs for natural gas and renewable energy generation technologies have declined (NREL 2017). Natural gas generation has benefited not only from historically low gas prices because of the high abundance of shale but also from improving turbine technology. Renewable energy technologies such as wind and solar have similarly benefited from technology cost reductions. These factors have resulted in natural gas combustion turbine and renewable technologies increasing their contribution to the net generation $\operatorname{mix}^{5}$ at the expense of coal and older oil and natural gas steam generation. To date, about $70 \mathrm{GW}$ of new generation capacity has been announced and is planned to come online across the Western Interconnection from 2017-2026 to meet load and renewable portfolio standards requirements, with $84 \%$ of this new capacity expected to come from wind, solar, and natural gas (Sandia 2017). Given that renewable generation is often more remote from load centers than new natural gas-fired power plants, more transmission capacity might be needed if the growth in renewable generation capacity is greater than expected.

Figure 2 provides a graphical representation of currently proposed transmission lines within Section 368 regions. In addition, the Solar Energy Zones (SEZ) and Western Renewable Energy Zones (WREZ) are highlighted to emphasize how potential transmission needs and the Section 368 corridors could be affected should these renewable resources be tapped. SEZ are defined by the BLM as areas well suited for utility-scale production of solar energy in which solar energy and associated transmission infrastructure development will be prioritized (BLM 2014). WREZ arose out of a need identified by the Western Governors Association to find sites throughout the Western Interconnection that have potential for large-scale renewable resource development while maintaining low environmental impacts (Western Governors Association and DOE 2009). This map illustrates areas where energy corridors can be confirmed as useful to existing transmission plans or areas where additional energy corridors might be needed. The location of remote renewable energy resources (potentially indicated by SEZ and WREZ locations) could identify transmission end points where there might be demand for energy corridors to deliver load to population centers.

${ }^{5}$ New capacity additions less retirements 

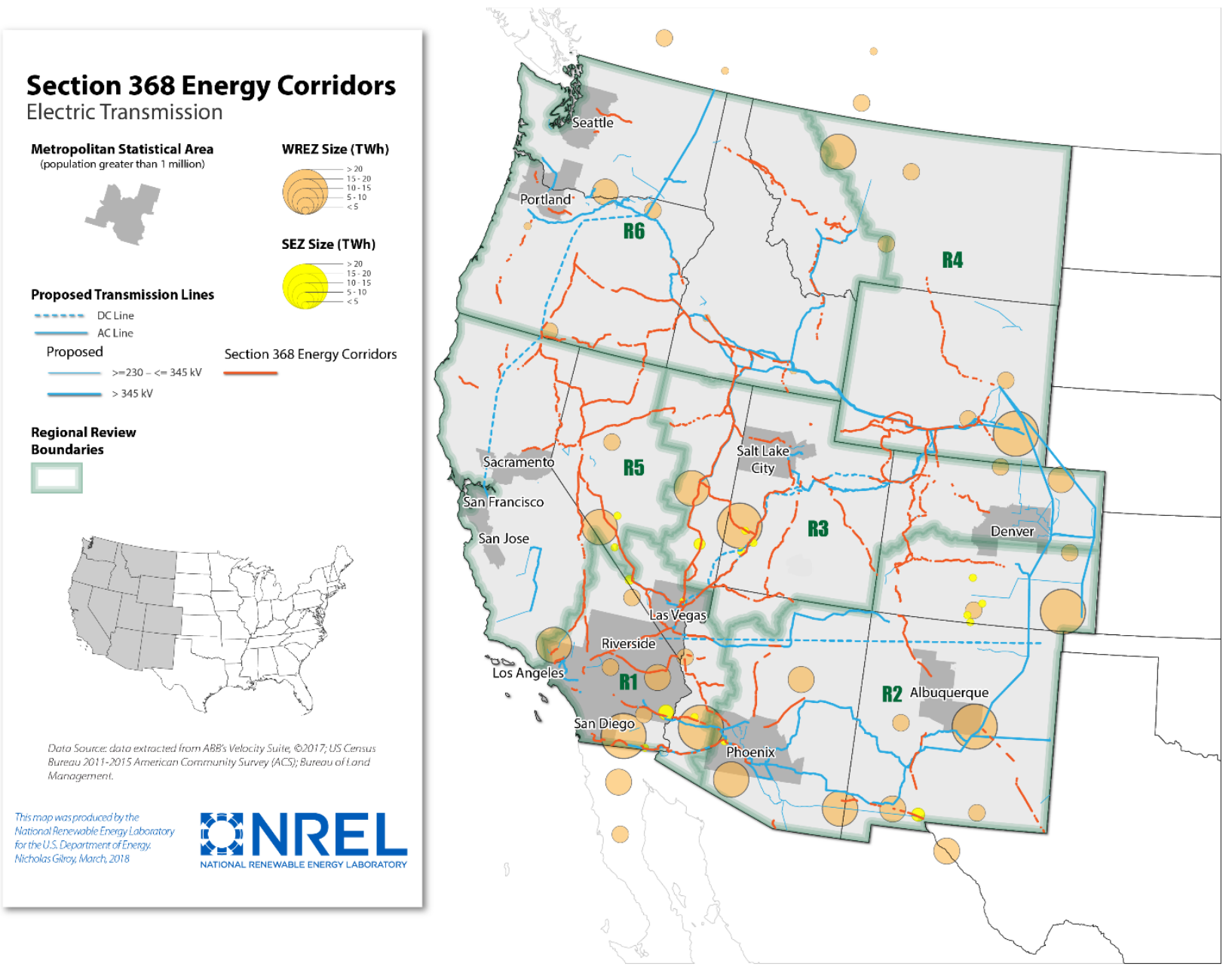

Figure 2. Highlighted proposed transmission lines and Section 368 corridors with SEZ and WREZ

On the other hand, several factors might counter the demand for new transmission to support utility-scale renewable energy development. The retirement of coal, nuclear, and older natural gas generation in the West might reduce the demand on existing transmission because these lines become underused and are thus available for use by any new nearby generation. ${ }^{6}$ Further, although a new generation mix might call for improvements to the transmission system for reliability, it is possible that battery storage might play a significant role in reliability needs, obviating or reducing the reliability benefits of new transmission lines. Finally, the development of new natural gas and some renewable electric generation closer to cities, such as rooftop solar, could lessen the need for longer distance transmission projects. In summary, the evolving generation mix and the ultimate impact on the demand for transmission expansion is still unclear.

\section{Market Evolution}

Potential major changes in the West's wholesale electric market structure also might significantly influence utility procurement decisions and the need for transmission development. Outside of California, much of the western electricity market has been operated by separate

\footnotetext{
${ }^{6}$ Specifically, Navajo Generating Station, Four Corners Generating Station, and the Intermountain Power Plant, which are all served by 50-kV lines, are expected to retire between 2020 and 2025.
} 
balancing authorities. These balancing authorities have historically been charged with planning and scheduling resources, maintaining generation balance, and supporting interconnection frequency in real time within their jurisdictions.

Some balancing authorities have begun to pool resources and participate in regional markets, such as the California Independent System Operator grid operator's Energy Imbalance Market (EIM). The EIM is expanding as various regional utilities join the market to share short-term reserves. These reserves help provide flexibility in the context of increased variable generation, such as wind and solar. The California Independent System Operator, the entity responsible for long-term planning of generation and transmission for its members, is also attempting to expand its footprint into neighboring states for a broader wholesale electricity market. Elsewhere, utilities in the Mountain West Transmission Group (utilities from Colorado, Wyoming, and New Mexico) are actively pursuing becoming members of the Southwest Power Pool, which is part of the Eastern Interconnection.

Expanding markets and increased electricity trade could potentially increase the use of the transmission system and drive demand for new transmission. Integration of regional markets can allow utilities to share existing generation capacity, reducing their reliability costs (and the need to procure extra generation as a 'buffer') and decreasing curtailment of renewable generation, thereby operating more efficiently. These larger markets imply less new generation being built, but there is still potentially the need to move that shared generation to neighboring utilities. Integrated regional markets might also make it easier to identify new, economically viable transmission projects by looking at locational pricing and congestion data. However, it should be noted that, to date, integration between regional transmission organizations/independent system operator wholesale electricity markets has in practice been difficult to implement (versus individual utilities) and would require new transmission interties. ${ }^{7}$

\section{High Wind Energy Future Scenario}

As wind energy's share of the generation mix increases, there might be increased incidences of curtailment if no new transmission is built, which makes wind generation less economic. Curtailment occurs when a wind energy generator is asked to produce less power than is potentially available from the wind resource because of factors such as transmission congestion, system balancing challenges, or oversupply of economic energy.

One study reviewed for this synthesis, Reducing Wind Curtailment through Transmission Expansion in a Wind Vision Future (Jorgenson, Mai, and Brinkman 2017) found that with no new transmission, there would be significant curtailment in a $37 \%$ wind penetration scenario, with curtailment rates as high as $15.5 \%$. The study indicated that the installation of four proposed projects (Zephyr, TransWest Express, Mountain States Transmission Intertie, and SunZia Southwest Transmission Project) could reduce curtailment to 7.8\%. Although the study found that further transmission expansion continued to reduce curtailment, there were diminishing returns for expansions beyond the four projects listed here. These projects are in various stages of development, and the likelihood for construction of all projects is uncertain because of various factors.

\footnotetext{
${ }^{7}$ According to communications with the U.S. Office of Electricity Delivery and Energy Reliability
} 
A high wind energy future could increase the demand for use of the Section 368 corridors in Region 2 and Region 3 because of the geographic separation of remote wind resources from population centers, which could drive additional demand for transmission to interconnect them. However, while additional transmission infrastructure could alleviate curtailment, these expansions might not necessarily be economically competitive with other options (such as increased regional coordination and curtailment compensation schemes).

\section{Western Electricity Coordinating Council Common Case Scenario for Transmission Expansion}

WECC is a nonprofit entity that serves to ensure a reliable bulk electric system in the western United States, Canada, and the portion of Mexico in Baja California. WECC conducts bottom-up coordination of regional transmission plans done by the West's transmission owners and operators, supplemented by follow-on staff studies of future West-wide transmission adequacy to meet reliability needs, using a WECC-created model of the western electricity grid.

WECC has a stakeholder group - the Transmission Expansion Planning Policy Committee (TEPPC) - that assesses future transmission needs for the Western Interconnection. TEPPC defines a base case and prioritizes alternative scenarios for its biannual transmission adequacy study program. This study includes a 10 -year projection, informed by WECC member electric utilities, of future electricity needs, possible future resources, and projected new transmission.

This study looks at a common case scenario as well as various alternative scenarios, such as future reliability needs, high renewable generation (both utility-scale and distributed rooftop solar), changes in load, and generation retirements. This study is vetted by many stakeholders in the Western Interconnection, including regional transmission and generation planning groups, independent developers, regional market participants such as large utilities, and advocacy groups. The latest common case scenario ${ }^{8}$ attempts to determine an "expected future" (based on the projected load, resources, and transmission needs from 2015-2016 data) of the western power system in 2026, including changes to the generation mix and potential transmission congestion.

Under the 2026 common case scenario, there was minimal projected congestion and even decreases in congestion on paths from Utah to California and from the Pacific Northwest to California (WECC 2017). The two major factors cited for this finding were "the inclination for developers to build gas-fired generation near the load centers and renewable resources in-state with access to local transmission.” In addition, it appears that existing planned transmission projects under development and estimated by WECC to be built and energized in 2026 (as shown in Figure 3) will largely meet projected future transmission demands. This finding is replicated for the Southwest by the 2017 WestConnect Regional Transmission Planning study, which separately analyzed multiple WECC scenarios and found that there were no regional transmission needs in most of the Southwest under the base case assessment through 2026. The only scenario that revealed a regional transmission need was the high natural gas price

\footnotetext{
${ }^{8}$ The common case scenario is developed biannually using the previous year's data for projection 10 years out.
} 
sensitivity, which resulted in higher intrastate power congestion ${ }^{9}$ (largest in California) (WestConnect Planning Management Committee 2017).

Figure 3 is a map of the transmission projects expected to be placed in service by $2026 .{ }^{10}$ These projects have already determined their proposed routing paths and do not necessarily represent future demand for Section 368 corridors; however, several of the proposed transmission projects will use segments of Section 368 corridors (facilities 1, 26, 7-11). One major proposed project that was not included in the WECC common case nor shown in Figure 3 is the SunZia transmission project, which would include two 500-kV transmission lines on paths through New Mexico and Arizona. Another project not included is the TransWest Express project, a 600-kV line through Wyoming, Colorado, Utah, and Nevada. Both projects used segments of West-wide Section 368 energy corridors, but they were not included in WECC's analysis because both did not meet the selection criteria during the study.

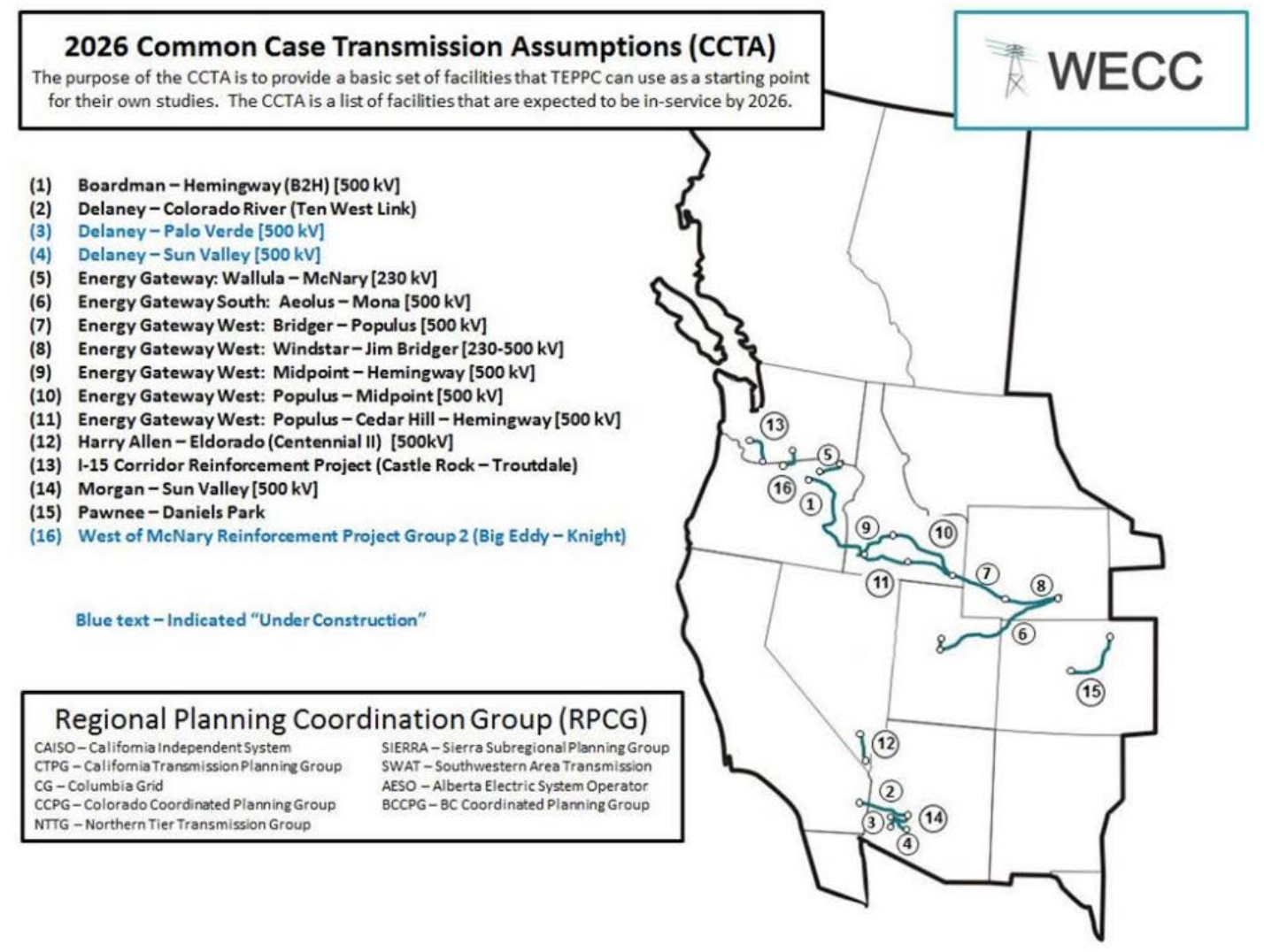

Source: WECC (2017)

Figure 3. WECC 2026 expected transmission expansions

\footnotetext{
${ }^{9}$ One potential explanation is that natural gas plants can be located close to electricity load centers, but this resource option will be less competitive with high gas prices. Instead, power demand would be met with alternate resources, which might be located more distant and cause more transmission congestion.

${ }^{10}$ The WECC Regional Planning Coordination Group developed a list of transmission projects having a high probability of being constructed within the 10-year study horizon. For more information on the evaluation criteria, see WECC (2016b).
} 


\section{Electric Transmission Planning: Region 2 and Region 3

\author{
WECC Transmission Path Implications for Region 2 and Region 3
}

Although there were no major increases in congestion by 2026 identified within the common case, TEPPC also developed multiple alternative scenarios to better understand the effects of high renewable penetration, coal retirements, natural gas price changes, and numerous other sensitivities on the western power system. WECC paths are groups of individual $230-\mathrm{kV}$ and larger transmission lines located in the Western Interconnection that generally connect two areas in the West. The locations of the paths in Region 2 and Region 3 are shown in Figure 4. The colors on the map show the congestion of the WECC paths as the percentage of time that the flow on the WECC paths is more than 75\% of their operating limits (U75). The study caveats that a high U75 does not necessarily indicate a path is overused and that many factors determine the lines’ operating limits.

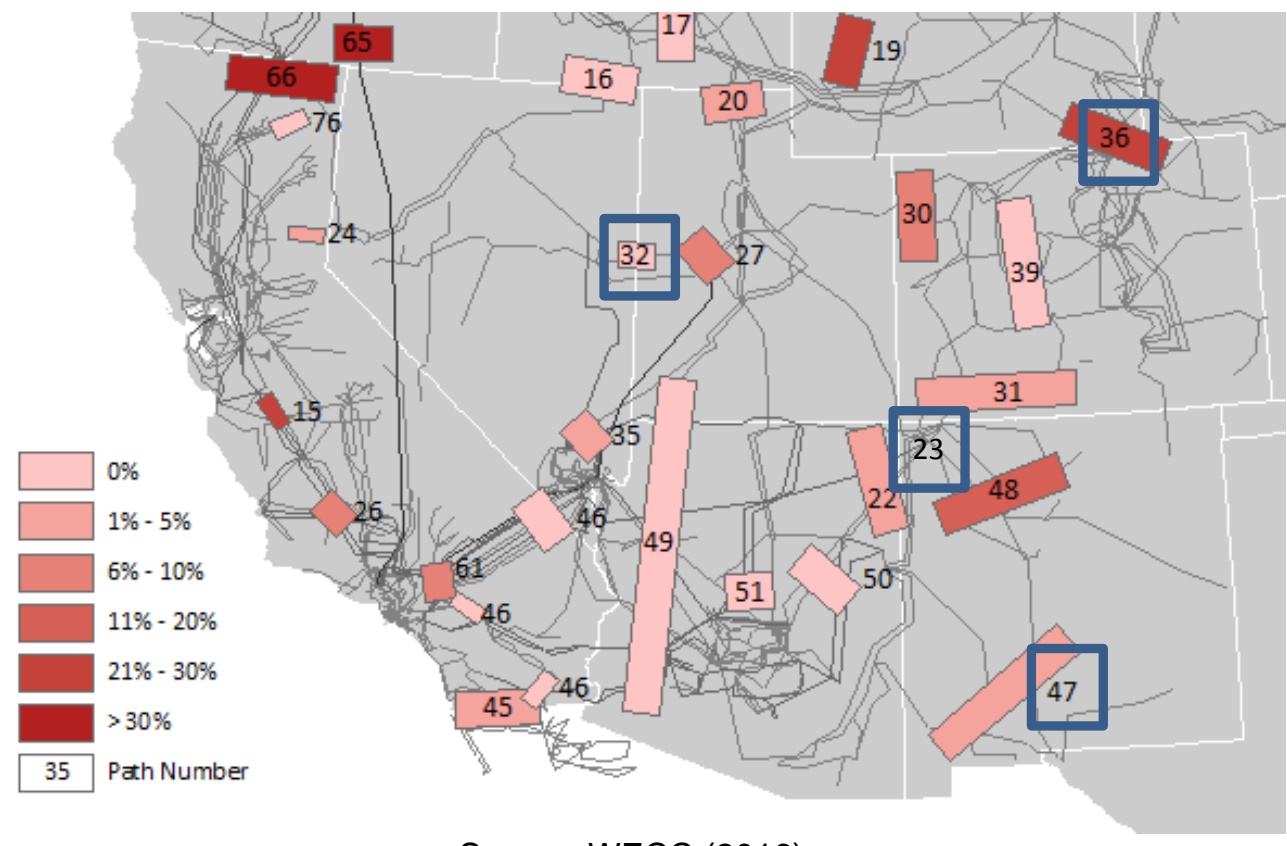

Source: WECC (2016)

Figure 4. Highlighted WECC major paths

After examining all TEPPC alternative scenarios, four heavily used WECC paths in Region 2 and Region 3 are near existing Section 368 corridors and might require additional transmission development to alleviate congestion: paths $23,32,36$, and $47 .{ }^{11}$ The locations of these paths are highlighted in Figure 4, and they are discussed in further detail next.

\footnotetext{
${ }^{11}$ The methodology for this analysis is discussed in Gazewood, Jensen, and Kuiper (2017). The analysis examined all TEPPC 2026 alternative scenarios. These reports can be found at https://www.wecc.biz/SystemAdequacyPlanning/Pages/TEPPC\%20Study\%20Program.aspx.
} 


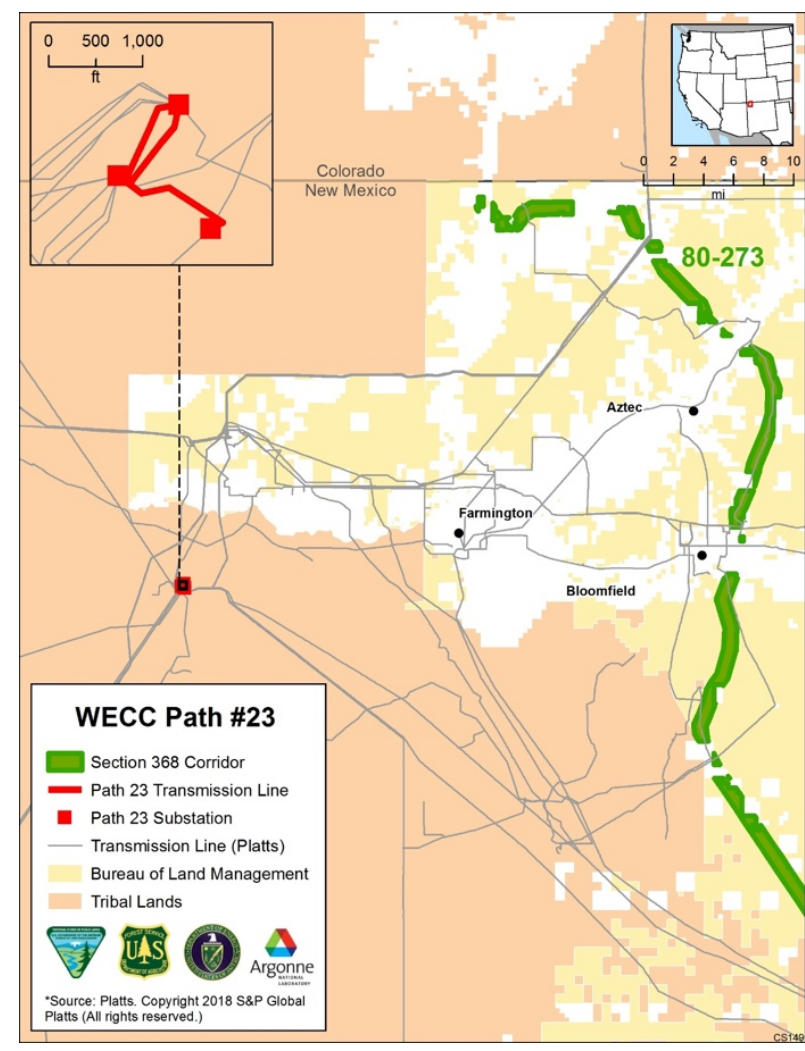

Figure 6. WECC Path \#32

Path 32 is called the Pavant IntermountainGonder 230-kV line. This path runs east-west across all of Nevada and the western half of the middle part of Utah. This path was congested under a high $\mathrm{CO}_{2}$ price or an increased renewable energy in Southern California and Southwest scenario. In 2014, WECC also proposed an energy corridor, called the WREZ UTCT to WREZ NVCT, along this path (Kuiper et al. 2014). Corridor 110-114 could potentially accommodate flow in the same direction because it crosses from Nevada to Utah in this vicinity, but the corridor diverges to the south as it crosses into Utah. There does appear to be potential for a corridor addition along Path 32 on BLM lands in Utah by extending corridor $110-114$ in a more northerly route to connect with corridor 114-241. As an indication of project interest in this corridor addition, the 500$\mathrm{kV}$ Cross-Tie Transmission project also proposes a route within Path 32.
Figure 5. WECC Path \#23

Path 23 is called the Four Corners Transformer and is close to corridor 80-273. Transmission flows in the area are generally from east to west because of the large amount of generation in the Four Corners area. This path was congested, or near its maximum capacity, under a high $\mathrm{CO}_{2}$ price scenario (assuming a price adder of $\$ 60$ per metric ton of $\mathrm{CO}_{2}$ ). Corridor 80-273 is nearby, approximately 25 miles to the east, but it has a generally north-south orientation and does not provide a westward connection. There does not appear to be potential for a corridor addition because Path 23 is predominantly located on Navajo Nation lands.

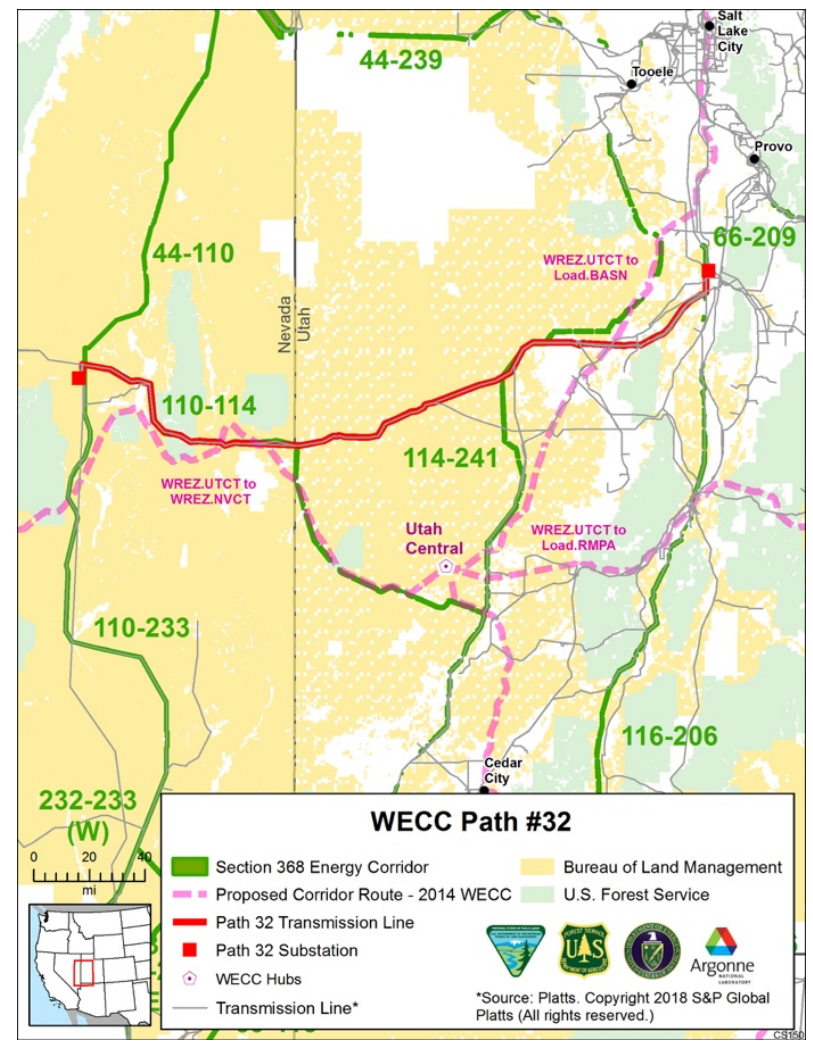




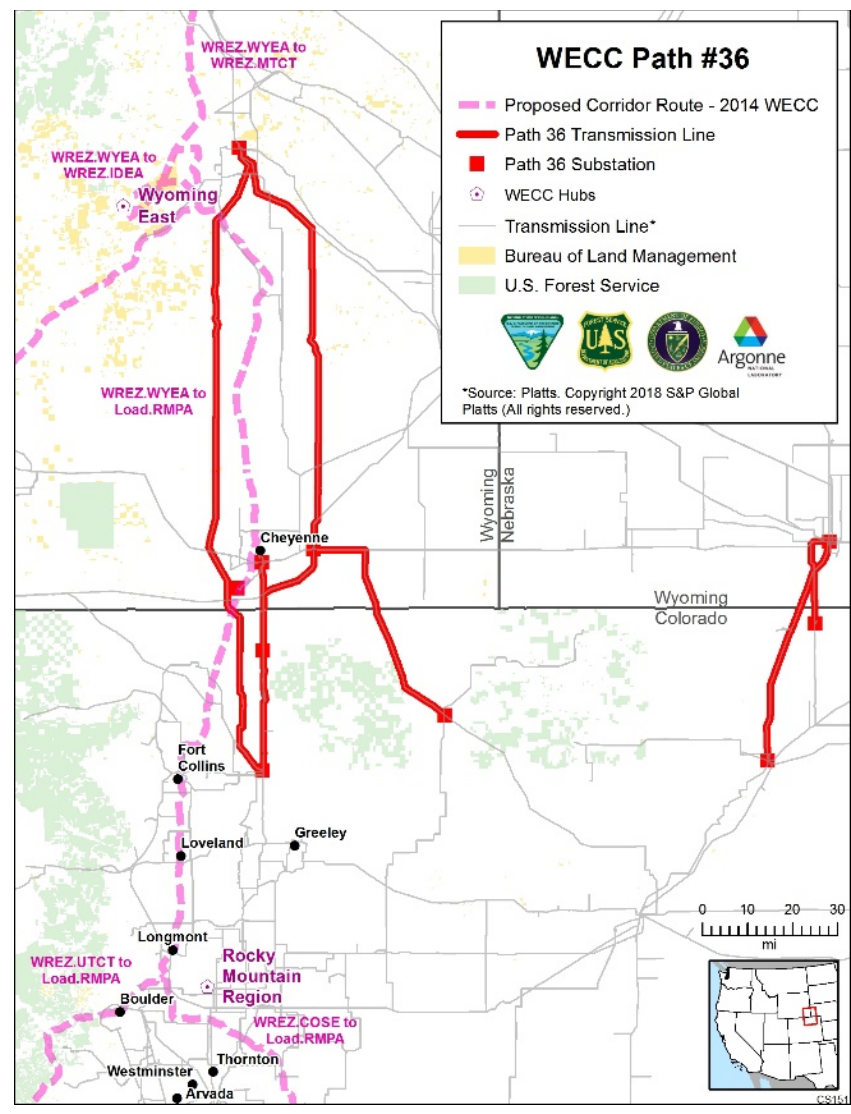

Figure 7. WECC Path \#36

Path 36, “TOT 3,” runs from northeastern Colorado to Wyoming and was congested under high renewable penetration scenarios, where there is a large build-out of wind energy. Historically, flow is north to south across the path. In 2014, WECC also proposed an energy corridor, called the WREZ-WYEA to Load RMPA, along this path (Kuiper et al. 2014). There is no BLM land in northeastern Colorado, but there is Forest Service land in the Pawnee National Grassland that could potentially be designated for a new corridor. In Wyoming, Corridor 78-85 might be relevant for partially relieving congestion on this path in the western direction, although this corridor is located in Region 4.

Figure 8. WECC Path \#47

Path 47, in southern New Mexico, is defined as the sum of flows on four lines in southwestern New Mexico. The lines range in size from $115 \mathrm{kV}$ to $345 \mathrm{kV}$. Path 47 was congested under a high coal retirement or high renewables scenario. In 2014, WECC also proposed an energy corridor, called the WREZ NMCT to Load DSW, along this path (Kuiper et al. 2014). Two recently authorized major transmission projects, SunZia and Southline, are also in the vicinity of Path 47 and might provide significant relief, once constructed.

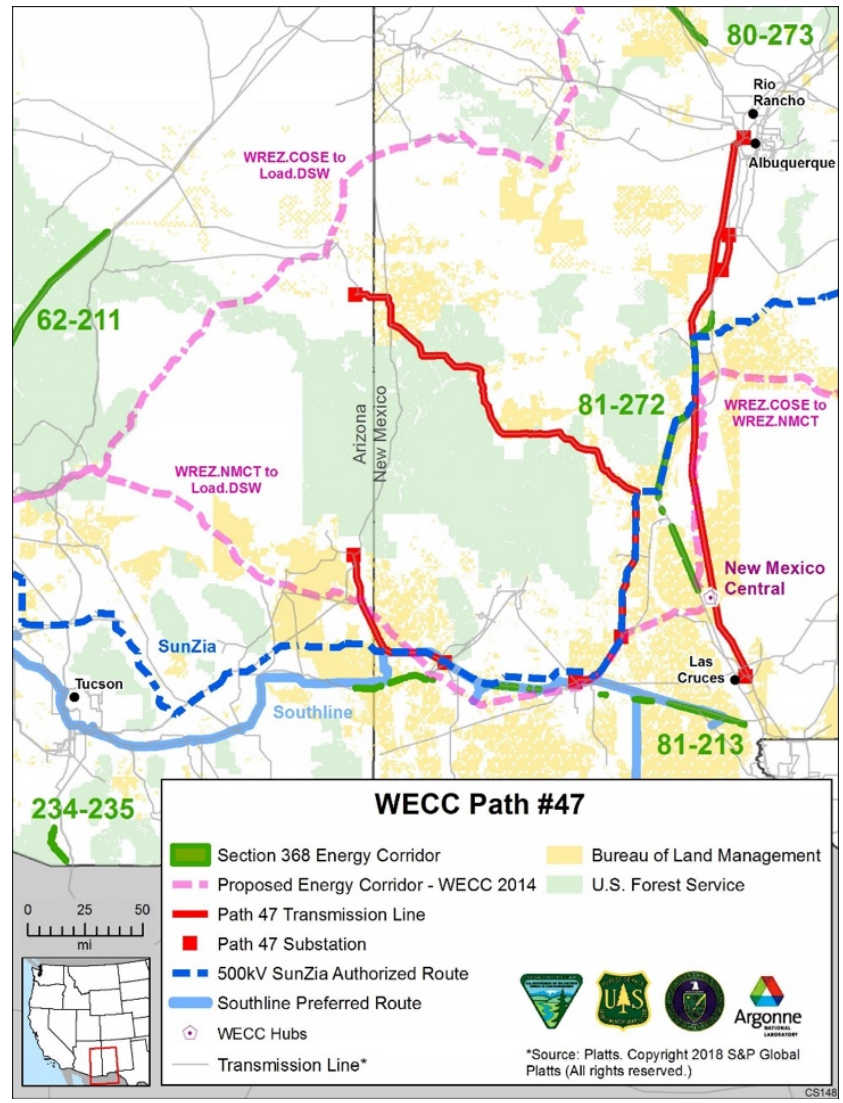


Table 2 summarizes the four WECC paths that could potentially be congested under alternative TEPPC scenarios.

Table 2. Congested WECC Paths under Alternative Scenarios

\begin{tabular}{|c|c|c|c|c|c|}
\hline $\begin{array}{l}\text { WECC } \\
\text { Path }\end{array}$ & $\begin{array}{l}\text { Constraining } \\
\text { Study }\end{array}$ & $\begin{array}{l}\text { Section } \\
368 \\
\text { Region }\end{array}$ & Location & $\begin{array}{l}\text { Section } \\
\quad 368 \\
\text { Corridors }\end{array}$ & $\begin{array}{c}\text { Opportunity } \\
\text { for Corridor } \\
\text { Addition }\end{array}$ \\
\hline 23 & High $\mathrm{CO}_{2}$ price & 2 & $\begin{array}{l}\text { Path } 23 \text { is in } \\
\text { northwestern New Mexico } \\
\text { and is defined as the flow } \\
\text { on the } 345 / 500-k V \\
\text { transformer. }\end{array}$ & $80-273$ & No \\
\hline 32 & $\begin{array}{l}\text { High } \mathrm{CO}_{2} \text { price } \\
\text { 22: increased } \\
\text { renewable energy in } \\
\text { Southern California } \\
\text { and Southwest }\end{array}$ & 3 & $\begin{array}{l}\text { Connection between Utah } \\
\text { and Nevada }\end{array}$ & $110-114$ & Yes \\
\hline 36 & $\begin{array}{l}\text { Coal retirement } \\
\text { High renewables } \\
\text { 21: additional wind } \\
\text { 22: increased } \\
\text { renewable energy in } \\
\text { Southern California } \\
\text { and Southwest }\end{array}$ & 3 and 4 & $\begin{array}{l}\text { Path } 36 \text { serves as the } \\
\text { transmission intertie } \\
\text { between northeast } \\
\text { Colorado and southeast } \\
\text { Wyoming. }\end{array}$ & $78-85$ & Yes \\
\hline 47 & $\begin{array}{l}\text { Coal retirement } \\
\text { High renewables }\end{array}$ & 2 & $\begin{array}{l}\text { Path } 47 \text { is defined as the } \\
\text { sum of flows on four lines } \\
\text { in southern New Mexico. } \\
\text { The lines range in voltage } \\
\text { from } 115 \mathrm{kV} \text { to } 345 \mathrm{kV} \text {. }\end{array}$ & $\begin{array}{l}81-213 \\
81-272\end{array}$ & No \\
\hline
\end{tabular}

\section{Utility Planning in Region 2 and Region 3}

Integrated Resource Plans, typically produced by investor-owned utilities, are another important source for anticipating future transmission demand. Many of these IRP's have longer time horizons than the TEPPC cases and can offer additional insights regarding the future beyond 2026 as well as how local utility contexts might influence transmission decisions in certain states and jurisdictions. The eight largest utilities in Region 2 and Region 3 that published IRP's include Arizona Public Service, Black Hills Energy, El Paso Electric, PacifiCorp, Public Service Company of Colorado (Xcel Energy), PNM, Salt River Project, and Tucson Electric Power (TEP). The utility service territories are shown in Figure 9. 


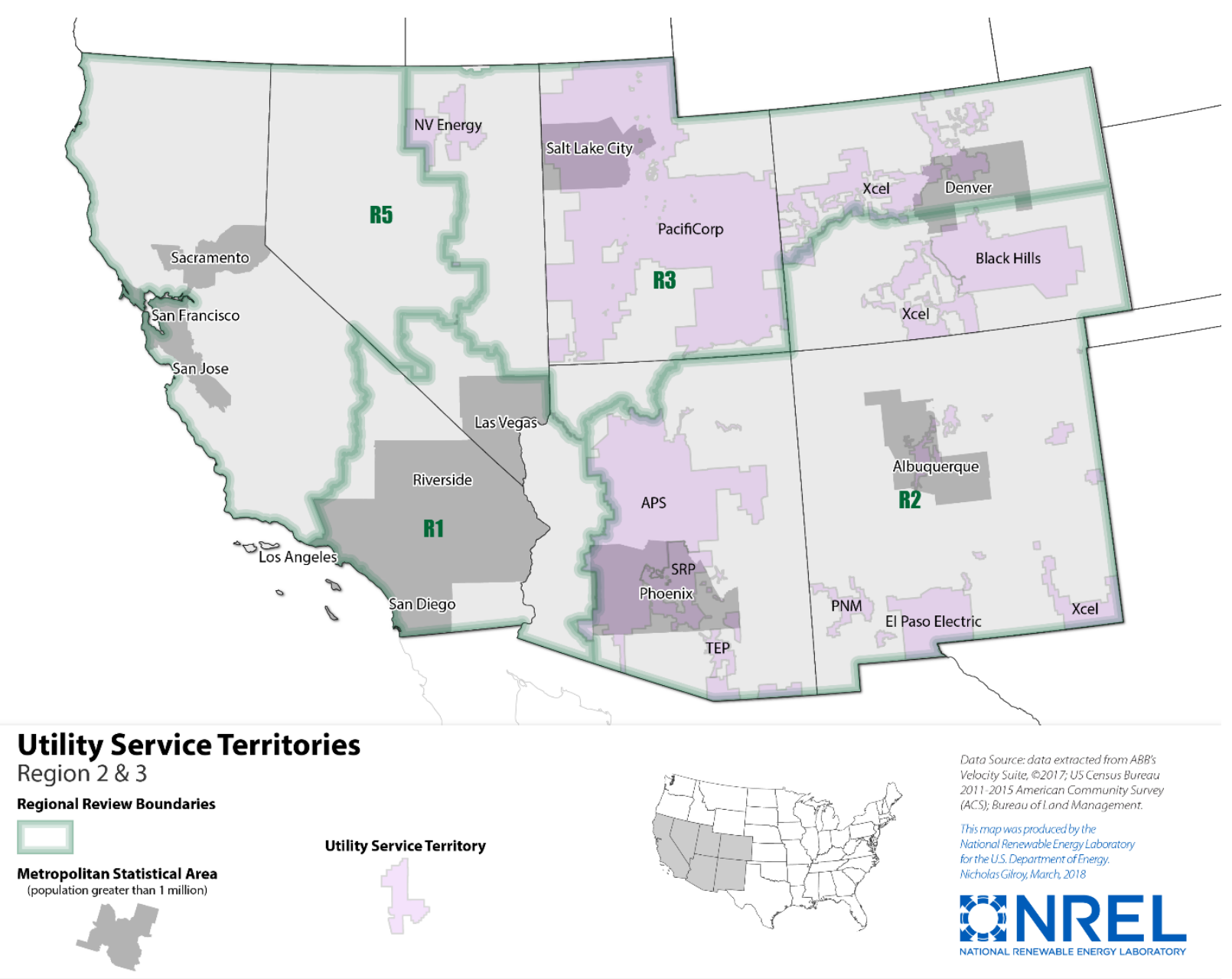

Figure 9. Service territories of investor-owned utilities with published integrated resource plans

Many of these utilities expect to develop new or upgrade existing transmission lines; however, many of the near-term transmission improvements (prior to 2025) are associated with existing projects that are already being permitted. Longer term, future capacity expansions in new, unconnected areas could represent an opportunity for development in Section 368 transmission corridors.

However, note that utility IRP plans might not always be accurate. A 2017 study, Exploring the Relationship Between Planning and Procurement in Western U.S. Electric Utilities, conducted at the request of the Western Interstate Energy Board's Committee on Regional Electric Power Coordination by Lawrence Berkeley National Laboratory, found a significant variation between some western electric utility IRP plans and actual electric utility resource procurements that occurred later (Carvallo, Sanstad, and Larsen 2017).

\section{Arizona}

Arizona Public Service expects to add transmission resources throughout its planning period (Arizona Public Service 2017). The plan specifically outlines 38 miles of 500-kV lines and 14 miles of 230-kV lines that will be constructed through 2022. These investments include the Morgan-Sun Valley 500-kV line, Ocotillo Modernization Project 230-kV line, and the North 
Gila-Orchard 230-kV, Line Circuit \#1. The Morgan-Sun Valley project is expected to be complete in 2017 and will serve the Phoenix metropolitan area while increasing export capability from the Palo Verde hub, which will increase access to solar and gas resources. It was authorized for 7 miles of BLM land, but it did not use existing energy corridors for geographic reasons. The Ocotillo project will interconnect flexible natural gas power plants in 2018. The North Gila project is a transmission rebuild that will be completed in 2021 and improve reliability in the Yuma metro area. The plan also assumes that new transmission lines would be needed to interconnect new natural gas resources from 2022 to 2032 that are not specified in the utility's plan. Arizona Public Service's current planned transmission projects are unlikely to use the 368 corridors.

Tucson Electric Power identified a need to adopt more flexible resources to accommodate increased renewable generation integration. TEP is also evaluating its participation in the western EIM, which could impact its flexible resource requirements going forward. Ultimately, TEP plans to select resources that allow them to use existing transmission lines, including the Pinal Central line that allows for access to resources associated with the Palo Verde hub. However, the utility is also considering two local 345-kV transmission lines, including the Irvington-Vail, Irvington-South Loop lines. These two projects are at the conceptual stage and would represent 36 miles of new transmission located near the Tucson metro area (Tucson Electric Power Company 2017). No BLM or Forest Service lands are near the TEP planned projects for potential designation of a new Section 368 corridor.

Salt River Project is not required to submit an IRP to the Arizona Corporation Commission, but it did complete an IRP for its governing board in 2014 that identifies an ongoing plan to procure primarily natural gas combustion turbine capacity as well as large renewable energy power purchase agreements (Salt River Project 2014). Their IRP does not identify any planned transmission projects, but their renewable energy power purchase agreement procurements might indicate future demand for transmission in the future.

\section{Colorado}

Black Hills Energy does not have any planned transmission projects that exceed $115 \mathrm{kV}$ (Black Hills Energy 2016). Black Hills Energy has identified three transmission constraints: transferring power from Pueblo to Canon City, Basulite Mesa to Midway, and La Junta to Rocky Ford. The first constraint can be addressed by developing a new 115-kV line (West Station-Canon West) that might be constructed in 2019-2020. Corridor 87-277 could potentially serve a small portion of the proposed 115-kV line. Black Hills Energy does not plan to address transmission constraints for the Basulite Mesa line, but the utility suggests that upgrades would be required to site new generation in that area. New generation in the La Junta/Rocky Ford area could reduce the third identified transmission constraint.

El Paso Electric's plan does not discuss any new transmission projects larger than $115 \mathrm{kV}$. In future plans, El Paso Electric might discuss new transmission needs, given that much of their planned added capacity is not necessary until 2026 or later (El Paso Electric Company 2015).

Xcel Energy expects the 345-kV Pawnee-Daniels Park transmission project in northeastern Colorado to be in-service during the resource acquisition period, but none of the proposed paths of this line are on BLM land or near Section 368 corridors. Xcel included 13 other transmission 
projects to meet future load and reliability requirements in its associated 10-year transmission plan, but none of these projects have received regulatory approval (Xcel Energy 2016). Xcel states that many of these transmission projects and investment decisions for new resources have been postponed because of slower load growth than expected. Because of its location, Corridor 144-275 is available for use, but is more likely to be used for generation carried to the Front Range. There does not appear to be any BLM or Forest Service lands near the PawneeDaniels Park transmission project.

\section{Utah}

PacifiCorp expects to add more than $3 \mathrm{GW}$ of renewable energy and $2 \mathrm{GW}$ of energy efficiency during its planning period (PacifiCorp 2017). PacifiCorp expects $1.1 \mathrm{GW}$ of this renewable energy to come from new Wyoming wind generation on the Gateway West transmission line project by 2020. The plan also assumes that about $700 \mathrm{MW}$ of wind capacity will be procured from Idaho by 2036. To interconnect this new generation, PacifiCorp expects to add transmission throughout its planning period. The Gateway South transmission project will extend 400 miles from the planned Aeolous substation in Wyoming to the existing Clover substation near Mona, Utah, and will be completed sometime in 2020-2024. In addition to these gateway projects, PacifiCorp plans to place the Oquirrh-Terminal 345-kV double-circuit transmission line, which travels 14 miles in northern Utah, in service in 2021. Both the Gateway West and Gateway South transmission projects use segments of West-wide energy corridors.

\section{New Mexico}

PNM Resource's transmission system has remained largely unchanged since 1985. PNM concludes that the retirement of San Juan Generating Station could cause reliability issues at the San Juan and Four Corners hub that sits between the Albuquerque and Phoenix load zones. PNM concluded that their transmission lines could benefit from new generation located at or near San Juan Generating Station and will consider this option in future plans. In addition, PNM identified that eastern New Mexico has significant wind resources, and new transmission would be necessary to access these resources. The utility plans to conduct a feasibility study relating to the expansion of the existing 345-kV Blackwater-Albuquerque line to access an additional $400 \mathrm{MW}$ of wind resources after 2022 (PNM 2014). If transmission development occurred in the Four Corners/San Juan region, then Corridor 80-273 could potentially be used.

\section{Nevada}

NV Energy's transmission grid comprises primarily 230-kV and 345-kV systems and serves the majority of Nevada; however, the transmission expansion plans in their current IRP include only one previously approved project that is still under development (120-kV line from Bordertown to the California substation). NV Energy does not expect many transmission limitations in the near term, and it expects the Bordertown-California line under development to alleviate these limitations. These limitations could be caused by future load growth west of Reno in an east-west direction. 


\section{Regional Natural Gas Implications}

Based on a nationwide DOE pipeline study, the outlook for interstate pipeline development in the West appears to be moderate to low. In a moderate or high renewable energy scenario, pipeline capacity demand would increase by $4 \%$ or $10 \%$ more than the base case, respectively; however, this is a relatively minimal impact because the reference case is projecting a relatively low 38 Bcf/day in additions from 2015 through 2030 (DOE 2015a). Further, half of the projected $38 \mathrm{Bcf} /$ day of capacity is expected to transport gas from the Marcellus formation, which is not located in the West. For context, between 1998 and 2013, nearly 127 Bcf/day of pipeline capacity was added in the United States.

Figure 10 shows areas of crude oil and natural gas production (Tight Oil and Gas Shale Plays), proposed pipelines and Section 368 energy corridors that could potentially transport this resource to refineries and, finally, the population centers where much of the resource is consumed. This map can be used to identify overlap between proposed pipelines and Section 368 corridors, such as the proposed pipeline running through southern New Mexico, which overlaps with Corridor 81-213. In addition, it can identify potential Section 368 corridor additions or modifications, such as the proposed pipeline running northeast from Phoenix to New Mexico, which partially crosses Forest Service land. Eastern Colorado also shows proposed pipelines that could indicate demand for Section 368 corridors, but there is minimal BLM and Forest Service land available for a Section 368 corridor addition (other than on the northern Colorado-Wyoming border).

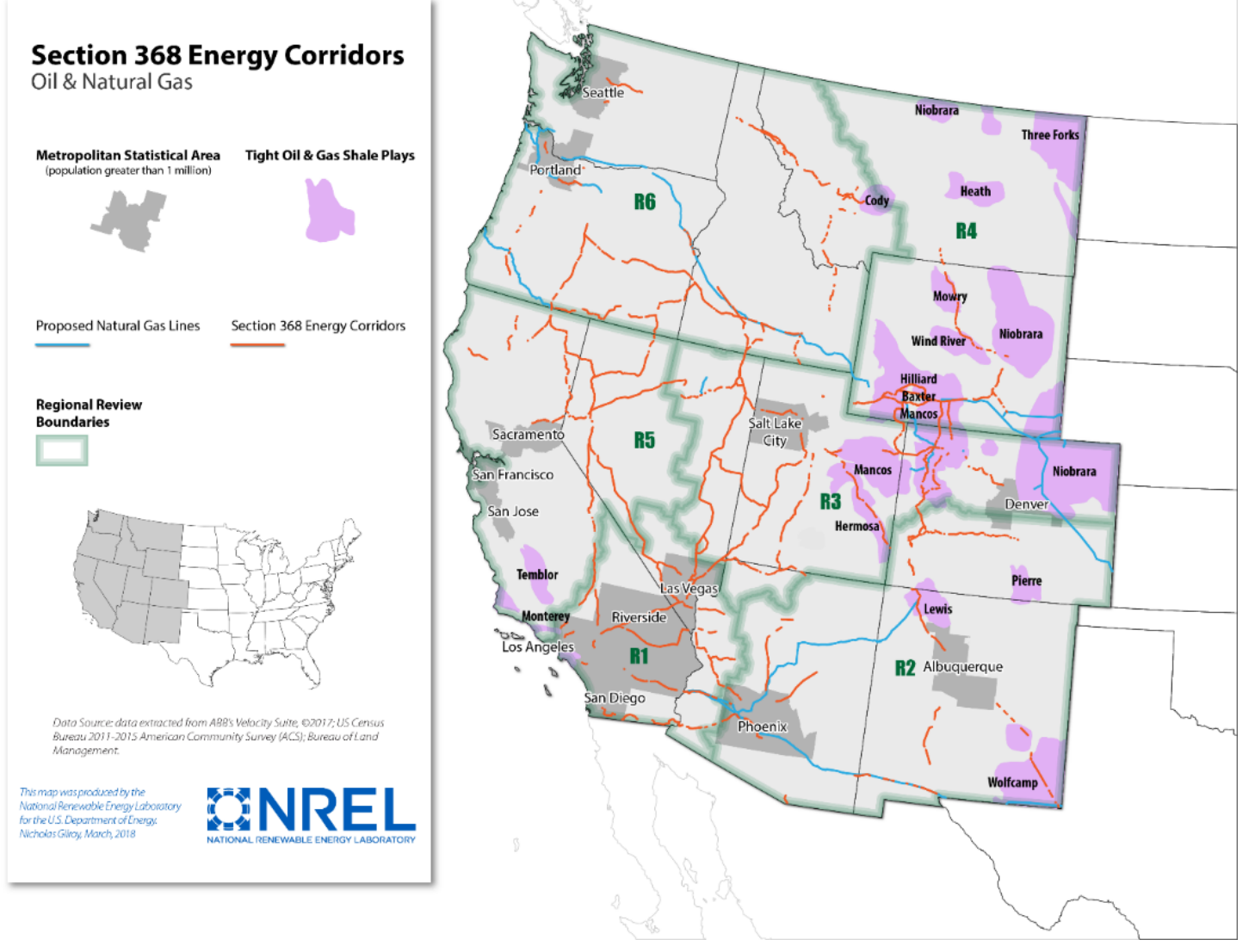

Figure 10. Highlighted proposed pipelines and Section 368 corridors 


\section{Drivers of Natural Gas Pipeline Development}

Although pipeline development is driven by numerous factors, one key market driver is basis differential, the difference in spot price between the Henry Hub (the pipeline that serves as the benchmark for the North American natural gas market) and the price of natural gas in a specific location. At a high level, comparing how the revenues from basis differentials compare to the cost of constructing pipelines will largely determine how much and in which locations pipeline capacity is likely to be added.

Another major driver of gas pipeline development is the retirement of coal plants and commensurate increased use of combined-cycle natural gas generators. Based on an NREL regional production model developed to evaluate the impacts on the Navajo Generating Station, existing combined-cycle natural gas generators in the Southwest have a relatively low capacity factor and will be used more heavily to partially make up for retiring coal plants (Hurlbut et al. 2016). In the DOE Natural Gas Infrastructure study (DOE 2015a), the modeled high renewable energy penetration cases resulted in an expected increase in pipeline capacity in the Southwest to bring natural gas from the Rockies and Southwest into and around California. In summary, the models indicate that changes in the generation mix, particularly increases in natural gas and renewable energy generation, will impact the demand for new natural gas pipelines.

\section{Natural Gas Pipeline Development Considerations for Region 2 and Region 3}

There are currently no active Federal Energy Regulatory Commission applications for interstate pipeline development in Region 2 or Region 3 (Federal Energy Regulatory Commission 2018). On an intrastate level, the variability and storage limitations of a natural gas system can also be a driver of pipeline development. Because some areas, such as the territory of El Paso Natural Gas in New Mexico, do not have geological conditions suitable for natural gas storage, pipelines' "linepack" (the storage capacity of the lines themselves) is sometimes the only way of managing variability within a natural gas transmission system. El Paso Natural Gas has developed market structures to accurately price these delivery services in response to linepack limitations. Future constrained linepack within the El Paso Natural Gas pipeline system could be a driver of additional intrastate Section 368 corridor demand in New Mexico.

A study by E3, which examined the impact of increased renewable penetration on pipeline variability in New Mexico, Colorado, and Arizona, found that existing pipelines can handle the increased variability associated with a $26 \%$ renewable energy penetration scenario (even under high demand conditions during the winter heating season, when flexibility is most likely to be constrained) (Schlag et al. 2014). The addition of renewable generation to an electric system reduces the overall level of gas demand while increasing its variability; however, the reduction in gas demand gives pipelines greater capability to handle the variable demand. The case study results indicate that this decrease in gas demand outweighs the impact of increased variability.

The natural gas generation plants in Power Plant Alley (primarily large generators in south-central Arizona), shown in Figure 11, represent a large share of the region's combined-cycle capacity and are technically able to accommodate the variability associated with $26 \%$ renewable energy penetration. Power Plant Alley runs through Region 1 and Region 2. Hydraulic simulations indicate that service of the variable demands of combined-cycle plants in Power Plant Alley is 
technically feasible at reasonable levels of pipeline capacity. Although the analysis identified operational challenges at high levels of linepack to Wenden, Arizona, these linepack levels are higher than current needs to meet delivery obligations to California. If California's need for natural gas increases in the future, pipeline capacity in Arizona might need to expand to accommodate the additional demand. Although this study did not examine the issue explicitly, increased demand for natural gas from California could also impact demand for interstate pipeline capacity in other states in the Southwest.
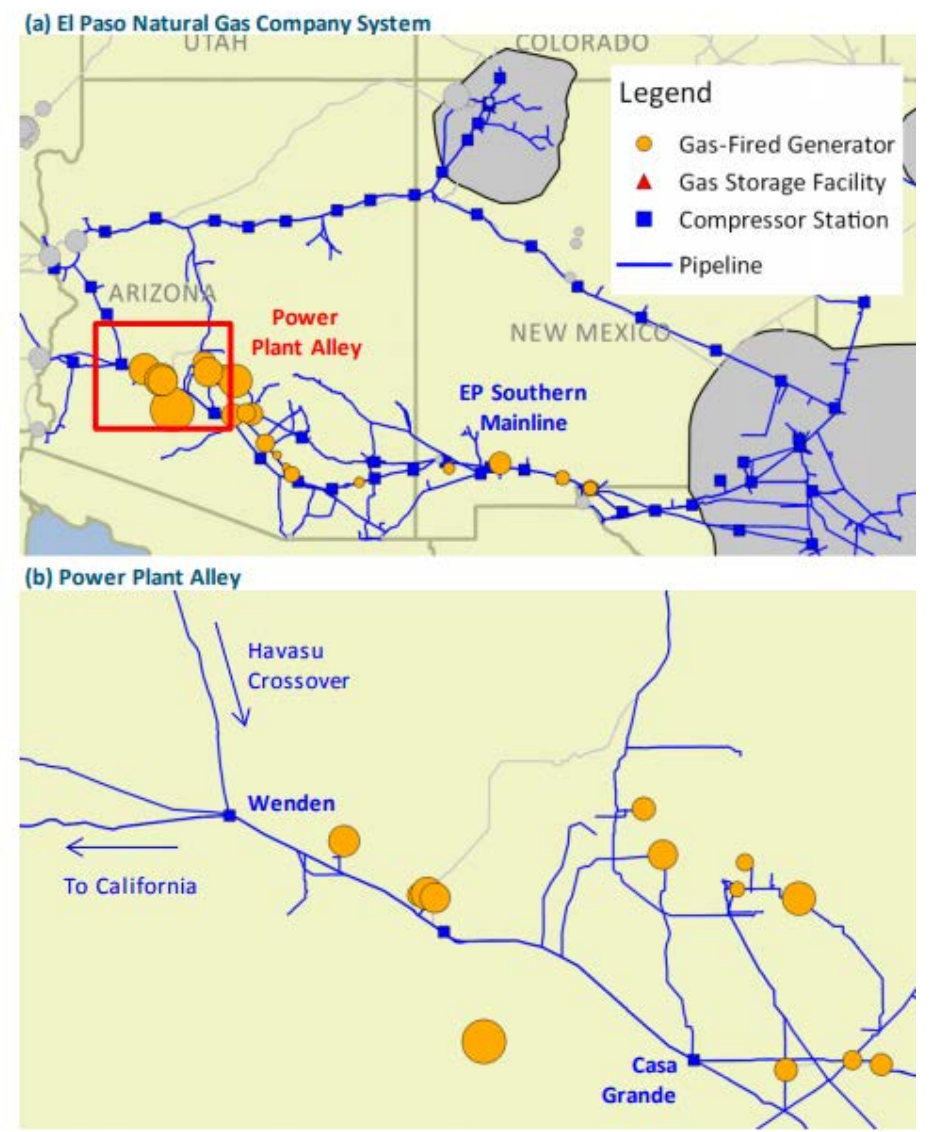

Source: Schlag et al. (2014)

Figure 11. E3 map of Power Plant Alley

Colorado has a large amount of existing flexibility in its pipeline system, likely resulting in reduced future demand for intrastate pipelines in this area. Unlike a number of other western pipeline systems, the Colorado Interstate Gas system consists of generally smaller diameter pipelines (6 to 16 inches in diameter), which physically limits the flexibility of the Colorado Interstate Gas system to meet variable loads; however, unlike New Mexico, Colorado does have significant injection and withdrawal capabilities in underground storage facilities located to the east and south of Denver. Xcel has a Natural Gas Core Delivery Area, where most of the gas plants are located. In 2013, in response to growing gas loads across all sectors in the Front Range, Colorado Interstate Gas and Xcel jointly developed the High Plains Expansion pipeline to increase deliverability of gas to the region, which has been placed in service and will likely meet this area's needs in the near term. As shown in Figure 11, there are proposed natural gas pipelines in eastern Colorado, but these are not located on or near BLM or Forest Service lands. 


\section{Summary of Implications for Section 368 Corridors in Region 2 and Region 3}

The electric power system in the West is undergoing a fast pace of change, thus affirming the need for adaptive management of the corridor network to meet changing energy demands, as envisioned by EPAct. With this caveat, some key implications for Section 368 corridors from this studies synthesis are summarized as follows:

- Transmission projects under development will largely meet projected future transmission demands according to the WECC common case ("expected future") scenario. With the assumed transmission projects in the WECC common case, there is minimal projected transmission congestion through 2026. The two major factors cited for the minimal changes in congestion were "the inclination for developers to build gas-fired generation near the load centers and renewable resources in-state with access to local transmission.”

- Under WECC’s alternative future scenarios with higher projected renewable energy development than expected, some corridors might see additional development interest. This is more likely to affect corridors in New Mexico, Nevada, and Utah than those in Colorado or Arizona.

- In-state renewable energy procurement requirements could reduce the demand for Section 368 corridor transmission development. California's procurement policy is the most significant, given that it represents the largest demand for renewable power across the West and requires 75\% of procurement to come from facilities that have "a first point of interconnection with a California balancing authority" or "have a first point of interconnection with distribution facilities used to serve end users within a California balancing authority area” (State of California 2015).

- The outlook for interstate natural gas pipeline development in the West is moderate to low. Existing natural gas pipeline infrastructure in Colorado, New Mexico, and Arizona would be able to handle the variability associated with $26 \%$ of power generation coming from renewable energy; however, additional pipelines might be needed if California's demand for natural gas increases in the future or if expansion of natural gas generation in the West is greater than predicted.

- It should be noted that many dynamic trends, such as the changing generation mix, state and federal policies, decreasing costs of natural gas and renewable energy, as well as market evolution, might influence the future use of Section 368 corridors. These factors could provide either upward or downward pressure on the need for increased transmission in the West. 


\section{References}

ABB. 2017. "Velocity Suite Database."

Argonne National Laboratory. "Regions for Review of Section 368 Corridors." http://corridoreis.anl.gov/maps/data/Regions_Overview_Map.pdf.

Arizona Public Service Company. 2017. Integrated Resource Plan (Technical Report). Phoenix, AZ. https://www.aps.com/library/resource\%20alt/2017IntegratedResourcePlan.pdf.

Barrows, Clayton, Trieu Mai, Scott Haase, Jennifer Melius, and Meghan Mooney. 2016. Renewable Energy Deployment in Colorado and the West: A Modeling Sensitivity and GIS Analysis (Technical Report NREL/TP-6A20-65350). Golden, CO: National Renewable Energy Laboratory. https://www.nrel.gov/docs/fy16osti/65350.pdf.

Black Hills Energy. 2016. 2016 Electric Resource Plan. Rapid City, South Dakota. https://www.blackhillsenergy.com/sites/blackhillsenergy.com/files/coe_att-ls-1-2016-bhce-erp6-3-16.pdf.

California Energy Commission. 2016. Transmission Capability and Requirements Report: Transmission Technical Input Group - Renewable Energy Transmission Initiative (Technical Report). Sacramento, CA. http://docketpublic.energy.ca.gov/PublicDocuments/15-RETI02/TN214168_20161025T091645_Transmission_Capability_and_Requirements_Report.pdf.

California Public Utilities Commission. 2018. "RPS Reports and Data.” RPS Executed Projects: Public Data. http://www.cpuc.ca.gov/RPS_Reports_Data/.

Carvallo, Juan, Alan Sanstad, and Peter Larsen. 2017. Exploring the Relationship between Planning and Procurement in Western U.S. Electric Utilities (Technical Report LBNL2001029). Berkeley, CA: Lawrence Berkeley National Laboratory. https://emp.lbl.gov/publications/exploring-relationship-between

Corbus, D., D. Hurlbut, P. Schwabe, E. Ibanez, M. Milligan, G. Brinkman, A. Paduru, V. Diakov, and M. Hand. 2014. California-Wyoming Integration Study: Phase 1-Economic Analysis (Technical Report NREL/TP-6A20-61192). Golden, CO: National Renewable Energy Laboratory. https://www.nrel.gov/docs/fy14osti/61192.pdf.

El Paso Electric Company. 2015. Integrated Resource Plan of El Paso Electric Company for the Period 2015-2034. El Paso, TX. https://www.epelectric.com/document/integrated-resource-plan2015-2034-07-16-2015.

Federal Energy Regulatory Commission. 2018. "Major Pipeline Projects Pending (Onshore).” https://www.ferc.gov/industries/gas/indus-act/pipelines/pending-projects.asp.

Frew, Bethany, Trieu Mai, Venkat Krishnan, and Scott Haase. 2016. Utility-Scale Photovoltaic Deployment Scenarios of the Western United States: Implications for Solar Energy Zones in Nevada (Technical Report NREL/TP-6A20-67066). Golden, CO: National Renewable Energy Laboratory. https://www.nrel.gov/docs/fy17osti/67066.pdf. 
Gazewood, Jensen, and Kuiper. 2017. "WECC 2026 Studies Program: Sec. 368 Energy

Corridors Spatial Assessment Status Update.”

https://www.wecc.biz/Reliability/WECC\%202026\%20Study\%20Program\%20-

\%20BLM\%20Sec.\%20368\%20Energy\%20Corridor\%20Spatial\%20Assessment\%20Presentation .pdf.

Hurlbut, David, Scott Haase, Clayton Barrows, Lori Bird, Greg Brinkman, Jeff Cook, Megan Day, Victor Diakov, Elaine Hale, David Keyser, Anthony Lopez, Trieu Mai, Joyce McLaren, Emerson Reiter, Brady Stoll, Tian Tian, Harvey Cutler, Dominique Bain, and Tom Acker. 2016. Navajo Generating Station \& Federal Resource Planning Volume 1: Sectoral, Technical, and Economic Trends (Technical Report NREL/TP-6A20-66506). Golden, CO: National Renewable Energy Laboratory. https://www.nrel.gov/docs/fy17osti/66506.pdf.

Jorgenson, Jennie, Trieu Mai, and Greg Brinkman. 2017. Reducing Wind Curtailment through Transmission Expansion in a Wind Vision Future (Technical Report NREL/TP-6A20-67240). Golden, CO: National Renewable Energy Laboratory. https://www.nrel.gov/docs/fy17osti/67240.pdf.

Kuiper, James A., Brian L. Cantwell, Kevin J. Hlava, H. Robert Moore, Andrew B. Orr, and Emily A. Zvolanek. 2014. Analysis of Potential Energy Corridors Proposed by the Western Electricity Coordinating Council (Technical Report ANL/EVS-14/3). Argonne, IL: Argonne National Laboratory. http://www.ipd.anl.gov/anlpubs/2014/02/103660.pdf.

Lawrence Berkeley National Laboratory. 2017. "Renewables Portfolio Standards Resources.” https://emp.lbl.gov/projects/renewables-portfolio.

Nikolewski, Rob. 2018. "Nuclear Power Receives Its Death Sentence in California: Regulators Vote to Shut Down Diablo Canyon, California’s Last Nuclear Power Plant.” LA Times, January 11, 2018. Accessed April 9, 2018. http://www.sandiegouniontribune.com/business/energygreen/sd-fi-diablocanyon-shutdownvote-20180111-story.html.

National Renewable Energy Laboratory (NREL). 2017. “Annual Technology Baseline 2017.” https://data.nrel.gov/files/71/2017-ATB-data.xlsm.

PacifiCorp. 2017. 2017 Integrated Resource Plan: Volume 1. Portland, OR. https://www.pacificorp.com/content/dam/pacificorp/doc/Energy_Sources/Integrated_Resource_P lan/2017_IRP/2017_IRP_VolumeI_IRP_Final.pdf.

Public Service Company of New Mexico (PNM). 2014. PNM Integrated Resource Plan: 20142033 (Technical Report PNM IRP 2014-2033). Albuquerque, NM. https://www.pnm.com/documents/396023/396193/PNM+2014+IRP/bdccdd52-b0bc-480b-b1d6cf76c408fdfc.

Salt River Project. 2014. SRP Integrated Resource Plan. Tempe, AZ. https://www.srpnet.com/about/stations/pdfx/2014irp.pdf.

Schlag, Nick, Arne Olson, Elaine Hart, Ana Mileva, Ryan Jones, Carlo Brancucci MartinezAnido, Bri-Mathias Hodge, Greg Brinkman, Anthony Florita, and David Biagioni. 2015. 
Western Interconnection Flexibility Assessment: Final Report (Technical Report). San Francisco, CA: Energy and Environmental Economics, Inc.

https://www.wecc.biz/Reliability/WECC_Flexibility_Assessment_Report_2016-01-11.pdf.

Schlag, Nick, Arne Olson, Gabe Kwok, Zach Ming, Mark Bolze, and Kevin Hemingway. 2014.

Natural Gas Infrastructure Adequacy in the Western Interconnection: An Electric System

Perspective-Phase 2 Report (Technical Report). San Francisco, CA: Energy and Environmental

Economics, Inc. http://westernenergyboard.org/wp-

content/uploads/2014/07/E3_WIEB_Ph2_Report_full_7-28-2014.pdf.

Schwartz, Lisa. 2012. Renewable Resources and Transmission in the West: Interviews on the Western Renewable Energy Zones Initiative. Denver, CO: Regulatory Assistance Project for Western Governors Association and U.S. Department of Energy.

http://westernenergyboard.org/wp-content/uploads/2014/11/02-2012WGA-Renewables-

Transmission-in-the-West-Interviews.pdf.

Sierra Pacific Power Company/NV Energy. 2016. Supply Side Plan: Technical Appendix.

Nevada PUC Docket No. 16-07001, Vol 10 of 16. Las Vegas, NV.

https://www.nvenergy.com/publish/content/dam/nvenergy/brochures_arch/about-nvenergy/ratesregulatory/recent-regulatory-filings/north/irp/Vol_10_SPPC_IRP.pdf.

Sandia National Laboratories. 2017. "Regional Power Markets Data Set.” SNL Subscription Service: Energy Commodities Data.

State of California. 2006. Senate Bill 1368, § Chapter 598.

State of California. 2015. Senate Bill 350, Section 21399.161 (A). https://leginfo.legislature.ca.gov/faces/billCompareClient.xhtml?bill_id=201520160SB350.

Tucson Electric Power Company. 2017 Integrated Resource Plan. Tucson, AZ. https://www.tep.com/wp-content/uploads/2017/04/TEP-2017-Integrated-Resource.pdf.

U.S. Bureau of Land Management (BLM). 2014. “Solar Energy Zones.” Last modified January 10, 2014. http://blmsolar.anl.gov/sez/.

U.S. Department of Energy (DOE). 2015a. Natural Gas Infrastructure Implications of Increased Demand from the Electric Power Sector (Technical Report). Washington, D.C.

https://energy.gov/sites/prod/files/2015/02/f19/DOE\%20Report\%20Natural\%20Gas\%20Infrastru cture\%20V_02-02.pdf.

U.S. Department of Energy (DOE). 2015b. Regional Evaluation of Renewable Energy Supply and Demand and Potential for Transmission Development (Technical Report). Washington, D.C. https://www.ladwp.com/cs/idcplg?IdcService=GET_FILE\&dDocName=OPLADWPCCB45922 $\underline{0 \text { \&RevisionSelectionMethod=LatestReleased. }}$

U.S. Department of Energy (DOE). 2017. Staff Report to the Secretary on Electricity Markets and Reliability. (Technical Report). Washington, D.C. https://energy.gov/downloads/downloadstaff-report-secretary-electricity-markets-and-reliability. 
U.S. Energy Information Administration. 2018a. "Electricity Data Browser.” Accessed February 1, 2018. https://www.eia.gov/electricity/data/browser/.

U.S. Energy Information Administration. 2018b. Annual Energy Outlook 2018. Washington, D.C.

WestConnect Planning Management Committee. 2017. WestConnect Regional Transmission Planning: 2016-17 Planning Cycle-Regional Transmission Needs Assessment Report (Technical Report). Council, ID.

https://doc.westconnect.com/Documents.aspx?NID=17749\&dl=1.

Western Area Power Administration. 2015. Regional Evaluation of Renewable Energy Supply and Demand and Potential for Transmission Development (Technical Report). Lakewood, CO. https://www.ladwp.com/cs/idcplg?IdcService=GET_FILE\&dDocName=OPLADWPCCB45922 $\underline{0 \text { \&RevisionSelectionMethod=LatestReleased. }}$.

Western Electricity Coordinating Council (WECC). 2016a. "WECC Paths.” 2016 U75 for WECC Major Paths.

https://www.wecc.biz/epubs/StateOfTheInterconnection/Pages/Transmission/WECC-Paths.aspx.

Western Electricity Coordinating Council (WECC). 2016b. 2026 Common Case Transmission Assumptions (CCTA) (Technical Report). Salt Lake City, UT.

https://www.wecc.biz/Reliability/RPCG\%202026CCTA\%20Report\%202016\%2006\%2030.pdf.

Western Electricity Coordinating Council (WECC). 2017. TEPPC Study Report: 2026 PC1

Common Case (Technical Report). Salt Lake City, UT.

https://www.wecc.biz/Reliability/2026\%20PC01\%20-\%20Common\%20Case\%20-

\%20Report.pdf.

Western Electricity Coordinating Council (WECC). 2018. State of the Interconnection: Winter 2018. Salt Lake City, UT. Accessed April 10, 2018.

https://www.wecc.biz/Reliability/State\%20of\%20the\%20Interconnection\%20Digest\%20(Winter \%202018).pdf.

Western Governors Association and U.S. Department of Energy (DOE). 2009. Western Renewable Energy Zones: Phase 1 Report. Washington, D.C.

https://energy.gov/sites/prod/files/oeprod/DocumentsandMedia/WREZ_Report.pdf.

Xcel Energy. 2016. 10-Year Transmission Plan for the State of Colorado. Denver, CO. http://www.transmission.xcelenergy.com/staticfiles/microsites/Transmission/Files/PDF/Planning /PSCO/Transmission-CO-PUC-Rule-3627-Colorado-10-Year-Transmission-Plan.pdf. 